\title{
Effects of different $n-6: n-3$ fatty acid ratios and of enterolactone on gene expression and PG secretion in bovine endometrial cells
}

\author{
Catherine Hallé ${ }^{1}$, Alan K. Goff ${ }^{2}$, Hélène V. Petit ${ }^{3}$, Richard Blouin ${ }^{1}$ and Marie-France Palin ${ }^{3 *}$ \\ ${ }^{1}$ Département de Biologie, Faculté des Sciences, Université de Sherbrooke, Sherbrooke, QC, Canada \\ ${ }^{2}$ Centre de Recherche en Reproduction Animale, Faculté de Médecine Vétérinaire, Université de Montréal, St-Hyacinthe, \\ $Q C$, Canada \\ ${ }^{3}$ Dairy and Swine Research and Development Centre, Agriculture and Agri-Food Canada, Sherbrooke, QC, Canada
}

(Submitted 28 January 2014 - Final revision received 15 September 2014 - Accepted 16 September 2014 - First published online 4 November 2014)

\section{Abstract}

Feeding flaxseed to dairy cows can modulate gene expression and PG synthesis in the uterus at the time of peri-implantation. The objectives of the present study were to determine which flaxseed components are responsible for these effects and how different endometrial cell types are affected. We evaluated the effects of six different linoleic acid $(n-6): \alpha$-linolenic acid $(n-3)$ ratios and three concentrations of the lignan enterolactone (ENL) on endometrial stromal cells (SC) and epithelial cells (EC). The mRNA abundance of genes with known or suspected roles in embryo survival or PG synthesis was evaluated, along with $\mathrm{PGE}_{2}$ and $\mathrm{PGF}_{2 \alpha}$ concentrations in culture media. The mRNA abundance of several genes was modulated by different fatty acid (FA) ratios and/or ENL, and this modulation differed between cell types. The FA4 (FA at an $n-6: n-3$ ratio of 4) treatment (rich in $n-3$ FA) increased the mRNA abundance of genes that have positive effects on uterine receptivity and implantation when compared with the FA25 (FA at an $n-6: n-3$ ratio of 25) treatment (rich in $n-6$ FA). ENL decreased $\mathrm{PGE}_{2}$ and $\mathrm{PGF}_{2 \alpha}$ concentrations in both cell types, and this reduction was associated with lower mRNA abundance of the PG synthase genes AKR1B1 and PTGES in SC. The combination of ENL with FA (FA4 treatment) resulted in the greatest reduction in PGF ${ }_{2 \alpha}$ concentrations when compared with the addition of FA (FA4) or ENL alone. Because of the known luteolytic properties of $\mathrm{PGF}_{2 \alpha}$, a reduction in endometrial $\mathrm{PGF}_{2 \alpha}$ secretion would favour the establishment and maintenance of pregnancy.

Key words: Cows: Endometrial cell culture: Fatty acids: Gene expression: Lignans

In ruminants, successful embryo implantation and survival is dependent on efficient recognition of the embryo by the endometrium and the continuous secretion of progesterone $\left(\mathrm{P}_{4}\right)$ by the corpus luteum $(\mathrm{CL})^{(1,2)}$. In cows, interferon- $\tau$ (IFNT) is the main anti-luteolytic pregnancy recognition signal secreted by the elongating conceptus between days 15 and 28 of gestation. IFNT prevents the regression of the CL through the suppression of endometrial oxytocin-induced luteolytic pulses of $\mathrm{PGF}_{2 \alpha}$ synthesis ${ }^{(2-4)}$. Particularly, it has earlier been reported that the establishment of pregnancy may also depend on increases in uterine $\mathrm{PGE}_{2}$ synthesis ${ }^{(5-7)}$ and on conceptus-secreted $\mathrm{PG}^{(8)}$. Consequently, variations in uterine and conceptus $\mathrm{PGE}_{2}$ and $\mathrm{PGF}_{2 \alpha}$ synthesis, along with variations in the $\mathrm{PGE}_{2}: \mathrm{PGF}_{2 \alpha}$ ratio, may affect embryo implantation and survival.

Prostaglandins are the derivates of PUFA. Arachidonic acid (AA), an $n-6$ fatty acid (FA), leads to the production of series 2 PG (including $\mathrm{PGF}_{2 \alpha}$ and $\mathrm{PGE}_{2}$ ), whereas $\mathrm{EPA}$, an $n$-3 FA, leads to the production of series $3 \mathrm{PG}^{(9)}$. The same elongase and desaturase enzymes can convert the main sources of

\footnotetext{
Abbreviations: AA, arachidonic acid; AKR1B1, aldo-keto reductase family 1, member B1; ALA, $\alpha$-linolenic acid; ANXA2, annexin A2; BEND, bovine immortalised endometrial; CL, corpus luteum; CO, control cells with no hormones; COP, control cells treated with progesterone; COPI, control cells treated with progesterone and recombinant ovine interferon- $\tau$; CXCL1O, chemokine (C-X-C motif) ligand 10; CYP39A1, cytochrome P450, family 39, subfamily A, polypeptide 1; DKK1, dickkopf homologue 1; E10, $10 \mu \mathrm{M}$-enterolactone; EC, epithelial cells; ENL, enterolactone; FA, fatty acids; FA0, linoleic acid: $\alpha$-linolenic acid ratio of 0; FA1, linoleic acid: $\alpha$-linolenic acid ratio of 1; FA4, linoleic acid: $\alpha$-linolenic acid ratio of 4; FA15, linoleic acid: $\alpha$-linolenic acid ratio of 15; FA25, linoleic acid: $\alpha$-linolenic acid ratio of 25; FA $\infty$, linoleic acid: $\alpha$-linolenic acid ratio of $\infty$; FBS, fetal bovine serum; FOS, FBJ murine osteosarcoma viral oncogene homologue; GEC, glandular epithelial cells; HBSS, Hanks' buffer saline solution; IFNT, interferon- $\tau$; IFIT3, interferon-induced protein with tetratricopeptide repeats 3; IRFG, interferon regulatory factor 6; ISG15, ISG15 ubiquitin-like modifier; LA, linoleic acid; LEC, luminal epithelial cells; OAS1, 2', $5^{\prime}$-oligoadenylate synthetase $1,40 / 46 \mathrm{kDa} ; \mathrm{P}_{4}$, progesterone; PARM1, prostate androgen-regulated mucin-like protein 1; PTGES, PGE synthase; roIFNT, recombinant ovine interferon- $\tau$; RPMI, Roswell Park Memorial Institute; SC, stromal cells; ZFP36L1, zinc finger protein 36, C3H type-like 1.
}

*Corresponding author: M.-F. Palin, fax +1 819564 5507, email mariefrance.palin@agr.gc.ca 
dietary $n$ - 6 FA (linoleic acid (LA)) and $n$ - 3 FA ( $\alpha$-linolenic acid (ALA)) to AA and EPA, respectively ${ }^{(9,10)}$. Therefore, competition between $n-3$ and $n-6$ FA occurs for the synthesis of PG, which may decrease the production of series 2 PG when there is an increased availability of dietary $n-3 \mathrm{FA}^{(9)}$. Indeed, it has been demonstrated that $n-3$ FA can reduce $\mathrm{PGF}_{2 \alpha}$ secretion from bovine endometrial cells in vitro ${ }^{(11)}$. Also, feeding cows with ALA and LA supplements decreased $^{(12)}$, and increased ${ }^{(13)}$, respectively, circulating series 2 PG metabolites in vivo. In addition to the abovementioned effects on elongase and desaturase enzymes, it has earlier been reported that $n-3$ and $n-6$ FA can modulate gene expression $^{(10)}$. For example, diets enriched in EPA and DHA, both $n-3$ FA found in fish oil, modulate bovine endometrial gene expression of PG endoperoxide synthase $(P G F S)$ and PGE synthase (PGES) in a manner that favours the establishment and maintenance of pregnancy ${ }^{(14-16)}$.

Flaxseed contains about $55 \%$ of total FA in the form of ALA and is known to have positive effects on fertility. For example, cows fed whole flaxseed have fewer pregnancy losses and lower plasma concentrations of series 2 PG than cows fed sunflower seed, which is rich in $\mathrm{LA}^{(17,18)}$. Moreover, cows fed with a flaxseed supplement have higher conception and lower embryo mortality rates than cows fed Megalac (rich in SFA) or micronised soyabeans (rich in LA) ${ }^{(19,20)}$.

Apart from its important ALA content, flaxseed is also one of the richest sources of plant lignans. Indeed, it contains high amounts of secoisolariciresinol diglucoside, which is mainly converted within the cows' rumen into the mammalian lignan metabolite enterolactone $(\mathrm{ENL})^{(21)}$. This lignan presents antioxidant activity and acts as a selective oestrogen receptor agonist $^{(22)}$, and thus could be responsible for some of the reproductive benefits observed when flaxseed is fed to cows. However, the effects of ENL on reproductive performances have been poorly explored so far.

At the time of peri-implantation, the expression of several endometrial genes is modulated to favour embryo implantation and development ${ }^{(23-25)}$. To better understand the mechanisms behind the positive effects of flaxseed on the fertility of dairy cows, we first performed a transcriptomic study comparing endometrial tissue transcripts of pregnant (day 17) dairy cows fed a supplement of $10 \%$ whole flaxseed with those fed a control diet ${ }^{(26,27)}$. Among all differentially expressed transcripts, genes involved in the synthesis of PG such as PGE synthase (PTGES) and aldo-keto reductase family 1, member B1 (AKR1B1, a PGF synthase) were identified. Genes known to be regulated by IFNT were also identified (e.g. 2',5'-oligoadenylate synthetase 1, 40/46 kDa $(O A S 1)^{(28)}$ and ISG15 ubiquitin-like modifier $\left.(I S G 15)\right)^{(29)}$ along with genes known or suspected to have a critical role in embryo survival (e.g. dickkopf homologue $1(D K K 1)^{(30)}$ and $\mathrm{Zn}$ finger protein 36, C3H type-like $1(\text { ZFP36L1) })^{(31)}$. As whole flaxseed was fed to cows in these previous experiments, it was not possible to determine whether differences in gene expression were due to the presence of $n-3 \mathrm{FA}$, flax lignans or both in the diet. Moreover, these studies provided information on gene expression levels in the whole endometrium with no distinction among cell types. It has earlier been demonstrated that epithelial cells (EC) and stromal cells (SC) from the cow endometrium exhibit specific functional properties, such as greater production of $\mathrm{PGF}_{2 \alpha}$ by EC and of $\mathrm{PGE}_{2}$ by $\mathrm{SC}^{(32)}$. Therefore, the present in vitro study was undertaken to identify the effects of $n$ - 3 FA (ALA), $n$ - 6 FA (LA) and ENL (mammalian lignan) on two bovine endometrial cell types, the SC and EC. More precisely, the objectives of the present study were to determine the effects of different LA:ALA ratios and of ENL on the mRNA abundance of selected genes having important roles in embryo implantation and survival and in the synthesis of $\mathrm{PGE}_{2}$ and $\mathrm{PGF}_{2 \alpha}$ in bovine endometrial primary cell culture.

\section{Materials and methods}

\section{Endometrial primary cell isolation and culture}

Uteri were collected from multiparous Holstein cows at stage 1 of the oestrous cycle (days 1-4) at the local slaughterhouse and transported on ice to the laboratory. A total of twelve cows were used to perform the experiments described in the present study. Uteri were selected based on their healthy and normal appearance and the presence of a corpus haemorrhagicum and a degraded CL from the previous cycle on the ovaries $^{(33,34)}$. Endometrial EC and SC were isolated using methods described in Fortier et al. ${ }^{(32)}$ and Xiao \& Goff ${ }^{(35)}$ with the following modifications. The cervix was removed and both horns were rinsed in sterile PBS $(1.37 \mathrm{M}-\mathrm{NaCl}$, $27 \mathrm{~mm}-\mathrm{KCl}, 100 \mathrm{~mm}-\mathrm{Na}_{2} \mathrm{HPO}_{4}, 18 \mathrm{~mm}-\mathrm{KH}_{2} \mathrm{PO}_{4}, \mathrm{pH}$ 7.4). The myometrium was removed by dissection and the uterine horns were carefully inverted with a long hook to expose the epithelium. Each horn was then cut into four to five sections that were each tied up at both ends. The tissue was then digested for $1 \mathrm{~h} 30 \mathrm{~min}$ at $37^{\circ} \mathrm{C}$ in Hanks' buffer saline solution (HBSS) without $\mathrm{Ca}$ and $\mathrm{Mg}$ (Invitrogen), supplemented with $0 \cdot 3 \%(\mathrm{v} / \mathrm{v})$ trypsin (Invitrogen) and an antibiotic-antimycotic $1 \times$ solution (ABAM) (Invitrogen), to collect luminal epithelial cells (LEC). This was followed by a second digestion for $1 \mathrm{~h} 15 \mathrm{~min}$ at $37^{\circ} \mathrm{C}$ in a new HBSs solution containing $0.06 \%$ $(\mathrm{v} / \mathrm{v})$ trypsin, $0.06 \%(\mathrm{w} / \mathrm{v})$ collagenase type 1 (Invitrogen) and ABAM to collect SC and glandular epithelial cells (GEC). After each digestion, the sections of the horns were rubbed lightly with the non-cutting edge of a cell lifter and rinsed twice in HBSS to free the cells. Right after the LEC suspension (first digestion) and the SC and GEC suspension (second digestion) were obtained, $10 \%(\mathrm{v} / \mathrm{v})$ fetal bovine serum (FBS) (Invitrogen) was added to inhibit trypsin activity. To purify LEC from the contamination by SC, the LEC suspension was centrifuged at $200 \boldsymbol{g}$ for at least 7 min to collect LEC clumps (SC remaining in the supernatant). LEC pellets were washed three times with HBSS, pooled and then suspended in $30 \mathrm{ml}$ of culture medium: Roswell Park Memorial Institute (RPMI)-1640 with L-glutamine and $25 \mathrm{~mm}$-HEPES (Invitrogen) supplemented with $10 \%$ (v/v) FBS and $100 \mu \mathrm{g} / \mathrm{ml}$ of Primocin (InvivoGen). To increase the total yield of EC, the SC and GEC suspension was filtered through a $40 \mu \mathrm{m}$ BD Falcon cell strainer (BD Biosciences). GEC clumps were recovered by backwashing the strainer with HBSS, whereas the SC passed 
through the strainer. The GEC suspension was then centrifuged at $200 \boldsymbol{g}$ for $5 \mathrm{~min}$. The pellets were washed one to two times with HBSS, pooled and then suspended in $20 \mathrm{ml}$ culture medium. To eliminate the remaining contaminating SC from the EC, LEC and GEC were plated in $92 \mathrm{~mm} \times 16 \mathrm{~mm}$ Petri dishes $(10 \mathrm{ml} /$ dish $)$ and incubated at $37^{\circ} \mathrm{C}$ with $5 \% \mathrm{CO}_{2}$ for $3 \mathrm{~h}$. The culture media containing the floating EC clumps were then collected delicately, thus leaving the contaminating SC adhered to the dish. The filtered SC suspension was centrifuged at $60 \mathrm{~g}$ for $5 \mathrm{~min}$ to further eliminate contaminating EC, and the supernatant was then centrifuged at $1000 \mathrm{~g}$ for $10 \mathrm{~min}$ to recover SC. The SC pellets were then resuspended in $4 \mathrm{ml}$ erythrocyte lysis buffer

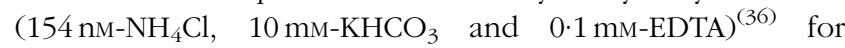
$7 \mathrm{~min}$ at room temperature and centrifuged at $1000 \mathrm{~g}$ for 5 min. The SC pellets were washed twice in HBSS, pooled and suspended in $20 \mathrm{ml}$ culture medium.

Cell counts were assessed using trypan blue staining (BioWhittaker) for the three purified cell types. The SC were plated in Costar six-well TC-treated plates (Corning) at $5 \times 10^{5}$ viable cells per well. At $3 \mathrm{~h}$ after SC plating, the culture medium was changed to get rid of the remaining contaminating EC clumps. LEC and GEC were pooled and plated in Corning CellBIND six-well plates (Corning) at a minimum of $4.5 \times 10^{5}$ viable cells per well. Cell isolation from one uterus provides enough cells to seed about thirty wells (six-well plates) for SC and thirty wells for EC. Both SC and EC (includes LEC + GEC) were cultured at $37^{\circ} \mathrm{C}$ with $5 \% \mathrm{CO}_{2}$ until $95-100 \%$ confluence $(6-8 \mathrm{~d})$ in $2 \mathrm{ml}$ culture medium supplemented with $10 \mathrm{ng} / \mathrm{ml}$ of $\mathrm{P}_{4}$ (Sigma-Aldrich) except for the cells with no hormones (CO). For the first $3 \mathrm{~d}$ of EC culture, FBS concentration was increased to $20 \%(\mathrm{v} / \mathrm{v})$. The culture medium was changed every $2-3 \mathrm{~d}$. The purity of cell cultures was determined using an inverted microscope, with cell morphology between SC and EC being distinctive (i.e. cuboidal or columnal for EC and fibroblast-like shapes for SC). At the end of the cell treatments, the average purity of SC and EC was estimated to be 97 and $95 \%$, respectively. In the present study, decision was made to use a monolayer cell-culture system in order to avoid cell proliferation inhibition associated with the use of Matrigel coating $^{(37-39)}$.

\section{Cytotoxicity assay}

To determine the cytotoxic effects of the different treatments (Table 1) on endometrial cells, preliminary experiments were conducted. Treatment of cells with ENL, recombinant ovine interferon- $\tau$ (roIFNT), or $\mathrm{P}_{4}$ had no effect on endometrial cell viability. However, when using a total FA concentration of $100 \mu \mathrm{M}$ for the different LA:ALA ratios studied, as previously reported for bovine immortalised endometrial (BEND) cells ${ }^{(40)}$, cytotoxicity was observed in SC for all ratios that contained ALA, whereas in EC, cytotoxicity was observed in the LA:ALA ratio of 25 (FA25) and $\infty$ (FA $\infty$ ). Therefore, to avoid the cell toxicity of FA, preliminary trials were conducted in order to determine the optimal total FA concentration to be used in cell cultures. Concentrations
Table 1. Description of the experimental treatments used in primary bovine endometrial cell cultures

\begin{tabular}{|c|c|c|c|c|c|}
\hline \multirow[b]{2}{*}{ Treatments ${ }^{\star}$} & \multicolumn{3}{|c|}{ Final concentrations } & \multirow[b]{2}{*}{$\begin{array}{c}\mathrm{P}_{4} \\
(\mathrm{ng} / \mathrm{ml})\end{array}$} & \multirow[b]{2}{*}{$\begin{array}{l}\text { rolFNT } \\
(\mathrm{ng} / \mathrm{ml})\end{array}$} \\
\hline & $\begin{array}{l}\text { LA } \\
(\mu \mathrm{M})\end{array}$ & $\begin{array}{l}\text { ALA } \\
(\mu \mathrm{M})\end{array}$ & $\begin{array}{l}\text { ENL } \\
(\mu \mathrm{M})\end{array}$ & & \\
\hline $\mathrm{CO}$ & - & - & - & - & - \\
\hline $\mathrm{COP}$ & - & - & - & 10 & - \\
\hline COPI & - & - & - & 10 & 45 \\
\hline FAO & - & 20 & - & 10 & 45 \\
\hline FA1 & 10 & 10 & - & 10 & 45 \\
\hline FA4 & 16 & 4 & - & 10 & 45 \\
\hline FA15 & 18.75 & 1.25 & - & 10 & 45 \\
\hline FA25 & 19.23 & 0.77 & - & 10 & 45 \\
\hline$F A \infty$ & 20 & - & - & 10 & 45 \\
\hline $\mathrm{E} 1$ & & - & 1 & 10 & 45 \\
\hline E10 & & - & 10 & 10 & 45 \\
\hline E1FA & 16 & 4 & 1 & 10 & 45 \\
\hline E10FA & 16 & 4 & 10 & 10 & 45 \\
\hline
\end{tabular}

LA, linoleic acid $(n-6) ;$ ALA, $\alpha$-linolenic acid $(n-3)$; ENL, enterolactone; $\mathrm{P}_{4}$, progesterone; rolFNT, recombinant ovine interferon- $\tau$; $C O$, control cells with no hormones; COP, control cells treated with $\mathrm{P}_{4}$; COPI, control cells treated with progesterone and rolFNT; FA, fatty acids; FA0, LA:ALA ratio of 0 ; FA1, LA:ALA ratio of 1; FA4, LA:ALA ratio of 4; FA15, LA:ALA ratio of 15; FA25, LA:ALA ratio of 25; FA $\infty$, LA:ALA ratio of $\infty$; E1, ENL 1; E10, ENL 10; E1FA, ENL 1 + FA4; E10FA, ENL 10 + FA4.

* The FA ratios represent the $n-6: n-3$ ratio (LA:ALA).

of $0,1,10,20,30,50$ and $100 \mu \mathrm{M}$-ALA were first tested in duplicate on confluent SC $(6-7 \mathrm{~d})$. Cytotoxicity was estimated as reported previously ${ }^{(41)}$ using crystal violet staining to quantify cell number in monolayer cultures after a $24 \mathrm{~h}$ period of exposure to FA. Briefly, the culture medium was aspirated and the cells were fixed with $10 \%$ buffered formalin for $10 \mathrm{~min}$. Formalin was then removed and the cells were stained with a solution of $1 \%$ crystal violet in $70 \%$ ethanol, for $15 \mathrm{~min}$ at room temperature. The wells were rinsed with distilled water to remove excess staining, and cell death was evaluated visually under an inverted microscope. Crystal violet stains the nuclei of live cells that remained attached to the surface of the six-well plate. For SC, the number of adherent cells was decreased in the wells that were exposed to ALA concentrations $\geq 30 \mu \mathrm{M}$, whereas the wells containing ALA concentrations of 1,10 and $20 \mu \mathrm{M}$ had no effect on cell number. For EC, there was no effect on adherent cell number in wells containing FA concentrations $\leq 50 \mu \mathrm{M}$, regardless of the LA:ALA ratio, after a $24 \mathrm{~h}$ period of exposition to FA. Based on these observations, a concentration of $20 \mu \mathrm{m}$ total FA was chosen for both cell types (Table 1).

\section{Product preparation for cell treatments}

LA and ALA were purchased from Cayman Chemical. In total, six FA stock solutions, each having a different LA:ALA ( $n-6$ : $n$-3) ratio (Table 1 ), were prepared at a total FA concentration of $20 \mathrm{~mm}$. FA were dissolved in pure ethanol purged with $\mathrm{N}_{2}$ and kept in darkness under $\mathrm{N}_{2}$ atmosphere at $4^{\circ} \mathrm{C}$. For ENL (Sigma-Aldrich), two stock solutions of 1 and $10 \mathrm{~mm}$ were prepared using pure ethanol purged with $\mathrm{N}_{2}$. These solutions were kept under $\mathrm{N}_{2}$ atmosphere at $4^{\circ} \mathrm{C}$. For $\mathrm{P}_{4}, 20 \mu \mathrm{g} / \mathrm{ml}$ of stock solution was prepared in culture medium and kept in darkness. Finally, $180 \mu \mathrm{g} / \mathrm{ml}$ of roIFNT (RayBiotech) stock 
solution were prepared on ice according to the manufacturer's instructions. It has earlier been demonstrated that bovine endometrial cells show similar responses to roIFNT and recombinant bovine IFNT ${ }^{(42)}$. The $\mathrm{P}_{4}$ and roIFNT were used to mimic the day-17 gestational situation of dairy cows ${ }^{(3,5)}$.

\section{Endometrial primary cell treatments}

Upon reaching confluence (6-7d), the culture medium was removed and each well was rinsed twice with $1 \mathrm{ml}$ HBSS. The cells were then incubated for $24 \mathrm{~h}$ at $37^{\circ} \mathrm{C}$ with $5 \% \mathrm{CO}_{2}$ in $2 \mathrm{ml}$ of a freshly prepared RPMI-1640 culture medium with L-glutamine and $25 \mathrm{~mm}$-HEPES and without $\mathrm{FBS}^{(11)}$ that contained $100 \mu \mathrm{g} / \mathrm{ml}$ of Primocin, a final concentration of $0 \cdot 2 \%$ ethanol $(\mathrm{v} / \mathrm{v}), 10 \mathrm{ng} / \mathrm{ml}$ of $\mathrm{P}_{4}{ }^{(3,43)}$ (except for the CO treatment) and the appropriate treatment (Table 1). The LA:ALA ratios of 4,15 and 25 were chosen because they correspond to physiological serum concentrations found in dairy cows fed $10 \%$ flaxseed (rich in ALA) in the diet (DM basis), Megalac/normal control diet and 10\% sunflower seed (rich in LA) in the diet, respectively ${ }^{(12,18)}$. The $1 \mu \mathrm{M}$-ENL treatment corresponds to the sum of ENL and ENL-glucuronide concentrations found in the serum of dairy cows receiving flax hulls and oil ${ }^{(21)}$. The effect of ENL was also evaluated in combination with a LA:ALA ratio of 4 (FA4) in order to mimic an in vivo situation of cows fed with $10 \%$ flaxseed supplements $^{(12,18,21)}$ and to detect potential synergetic effects between ENL and FA. The culture medium was then removed and each well was rinsed twice with $1 \mathrm{ml}$ HBSS. Cells were incubated for an additional $24 \mathrm{~h}$ in $2 \mathrm{ml}$ of a freshly prepared RPMI-1640 culture medium with L-glutamine and $25 \mathrm{~mm}-$ HEPES and without FBS, containing $100 \mu \mathrm{g} / \mathrm{ml}$ of Primocin, $10 \mathrm{ng} / \mathrm{ml}$ of $\mathrm{P}_{4}$ (except for the CO treatment) and $45 \mathrm{ng} / \mathrm{ml}$ of roIFNT ${ }^{(44)}$ (except for the $\mathrm{CO}$ and $\mathrm{CO}$ with $\mathrm{P}_{4}(\mathrm{COP})$ treatments). $\mathrm{P}_{4}$ and roIFNT were added to the cell-culture media in order to mimic the hormonal conditions of pregnancy during the peri-implantation period. At the end of roIFNT incubation, the culture medium was immediately collected from each well to measure the concentrations of $\mathrm{PGE}_{2}$ and $\mathrm{PGF}_{2 \alpha}$. Total RNA was extracted from the cells using the NucleoSpin RNA/Protein Kit (Macherey-Nagel), according to the manufacturer's instructions. For both cell types, each treatment was performed in triplicate and repeated four times (i.e. four cows for validation of the endometrial cellculture system, four cows to study the effects of FA ratios and four cows for ENL experiments). As the CO and COP treatments were prepared only to assess the effects of $\mathrm{P}_{4}$ and roINFT in our cell-culture system, the COPI treatment was used as the reference to compare the treatments and analyse the results.

\section{PG concentrations in culture media}

For both cell types, $\mathrm{PGF}_{2 \alpha}$ and $\mathrm{PGE}_{2}$ concentrations were measured in culture medium from each treatment, after a $24 \mathrm{~h}$ incubation period, using $\mathrm{PGF}_{2 \alpha}$ and $\mathrm{PGE}_{2}$ Enzyme Immunoassays kits (Assay Designs), following the manufacturer's instructions. Culture media obtained from duplicates were pooled for each treatment. Intra- and inter-assay $\mathrm{CV}$ were 3.74 and $6.21 \%$ for $\mathrm{PGF}_{2 \alpha}$ and 4.12 and $5.12 \%$ for $\mathrm{PGE}_{2}$, respectively. The $\mathrm{PGE}_{2}: \mathrm{PGF}_{2 \alpha}$ ratio was also measured for each treatment.

\section{Quantitative RT-PCR analyses of selected genes}

For cell cultures of SC and EC, reverse transcription of extracted RNA and real-time quantitative PCR analyses of selected genes were performed as described in Farmer et $a l .{ }^{(45)}$. The complementary DNA samples obtained from duplicate cell treatments were pooled. Amplification of selected genes and reference genes (RG) (glyceraldehyde-3phosphate dehydrogenase $(G A P D H)$, peptidylpropyl isomerase $\mathrm{A}(P P I A)$ and polyubiquitin) in bovines was performed using bovine-specific primer sequences (Table 2). Genes were selected from a previous study where endometrial tissue transcripts in dairy cows were hybridised to a twospecies complementary DNA microarray. This microarray was developed in our laboratory for profiling transcripts in sows and dairy cows, which are believed to be associated with embryo survival during the peri-implantation period ${ }^{(26,27)}$ The endometrial tissue samples of that previous study were collected on day 17 of pregnancy from dairy cows fed a control diet or a diet supplemented with $10 \%$ flaxseed, thus resulting in in vivo gene modulation by a diet rich in $n-3$ FA and lignans.

PCR amplification was performed in triplicate, and standard curves were established in duplicate for each gene. Standard curves were composed of serial dilutions of complementary DNA pools from the same cell type (SC or EC) and were used to obtain the relative mRNA abundance of selected genes using the standard curve method as described by Applied Biosystems ${ }^{(46)}$. Selection of the best RG for normalisation was made according to the geNorm software (http:// medgen.ugent.be/genorm/), which finds the optimum RG out of a group of candidate genes ${ }^{(47)}$. For both EC and SC cultures, a normalisation factor was calculated with the geometric mean of all three RG. This normalisation factor was then used as a RG. Selected genes and RG amplifications were run in separate assays. For each experimental sample, the mRNA abundance of selected genes relative to that of the RG was determined from the corresponding standard curves. Mean values were calculated from triplicate amplifications and relative quantity ratios were then obtained by dividing the relative quantity unit of selected genes by those of RG. These values were used to perform statistical analyses.

\section{Statistical analyses}

Statistical analyses were performed using the MIXED procedure of SAS (SAS Institute, Inc., 2002). The relative mRNA abundance data collected from SC and EC culture experiments were first analysed globally for all treatments (i.e. thirteen experimental treatments; see Table 1) using a one-way ANOVA followed by multiple comparisons of all treatments with the COPI treatment with a Dunnett adjustment. Then, a 
separate analysis for the effect of the different FA ratios on the relative mRNA abundance of selected genes was performed using a one-way ANOVA followed by an all-pairwise multiple comparison with a Tukey correction. The relative mRNA abundance of selected genes in primary cell cultures treated with ENL were also separately analysed according to a $3 \times 2$ factorial arrangement with ENL $(0,1$ or $10 \mu \mathrm{M})$ and FA (no added FA or $20 \mu \mathrm{M}-\mathrm{FA} 4$ ) concentrations as the main effects. Baseline (COPI) PG concentrations varied considerably between the different cell-culture experiments, but similar responses to the treatments were observed among the four cows. Therefore, PG data were analysed using Friedman's test on rank-transformed data with the same three steps as those described above for relative mRNA abundance data. Finally, to study the effects of $\mathrm{P}_{4}$ and roIFNT on endometrial cells, the relative mRNA abundance data for the CO, COP and COPI treatments were analysed separately using a oneway ANOVA, followed by an all-pairwise multiple comparison with a Tukey correction. Statistical significance was set at $P \leq 0.05$ and tendencies at $0.05<P \leq 0 \cdot 1$.

\section{Results}

\section{Validation of the endometrial cell-culture system}

To validate the cell-culture system, we evaluated cell response to the hormonal treatments that mimic the hormonal conditions of pregnancy during the peri-implantation period. This was achieved by comparing the relative mRNA abundance of selected genes in bovine endometrial cells treated with $\mathrm{P}_{4}$ (COP), $\mathrm{P}_{4}$ and roIFNT (COPI) or with no hormone

Table 2. Primer sequences used for quantitative RT-PCR

\begin{tabular}{|c|c|c|c|c|}
\hline Genes & & Primer sequence $5^{\prime}-3^{\prime}$ & Fragment size (bp) & GenBank accession no. \\
\hline \multirow[t]{2}{*}{$G A P D H$} & $\mathrm{~F}$ & TGACCCCTTCATTGACCTTCA & 66 & NM_001034034 \\
\hline & $\mathrm{R}$ & AACTTGCCGTGGGTGGAAT & & \\
\hline \multirow[t]{2}{*}{ PPIA } & $\mathrm{F}$ & GAGCACTGGAGAGAAAGGATTTG & 71 & NM_178320 \\
\hline & $\mathrm{R}$ & GGCACATAAATCCCGGAATTATT & & \\
\hline \multirow[t]{2}{*}{ Polyubiquitin } & $\mathrm{F}$ & TGGAGCCCAGTGACACCAT & 111 & NM_174133 \\
\hline & $\mathrm{R}$ & GGCCATCTTCCAGCTGCTT & & \\
\hline \multirow[t]{2}{*}{$A K R 1 B 1$} & $\mathrm{~F}$ & АСCTGGACСTСТАССТСАТССА & 72 & NM_001012519 \\
\hline & $\mathrm{R}$ & ССTCATCCAATGGGAAGAAGTC & & \\
\hline \multirow[t]{2}{*}{ ANXA2 } & $\mathrm{F}$ & AGCCCCTGTATTTTGGTGACA & 90 & NM_174716 \\
\hline & $\mathrm{R}$ & TGCGCGAGACCATGATTCTA & & \\
\hline \multirow[t]{2}{*}{ CTGF } & $\mathrm{F}$ & GAAGCTGACCTGGAGGAGAACA & 94 & AF309555 \\
\hline & $\mathrm{R}$ & TGCAGCCAGAAAGCTCAAACT & & \\
\hline \multirow[t]{2}{*}{ CXCL10 } & $\mathrm{F}$ & TTGCCACAATGAAAAAGAATGG & 92 & NM_001046551 \\
\hline & $\mathrm{R}$ & CCTTTGCTTGTTAATTGCTTTCAG & & \\
\hline \multirow[t]{2}{*}{ CYP39A1 } & $\mathrm{F}$ & GCTGGCTCTGTTGGAGATTCA & 104 & NM_001098938 \\
\hline & $\mathrm{R}$ & CCACCAAGTGGAGAGAACTCTGT & & \\
\hline \multirow[t]{2}{*}{$D K K 1$} & $\mathrm{~F}$ & TGTGTTGTGCTAGACATTTCTGGTC & 75 & NM_001205544 \\
\hline & $\mathrm{R}$ & TGTGCTTGGTGCACACTTGAC & & \\
\hline \multirow[t]{2}{*}{ FOS } & $\mathrm{F}$ & CTGAGCCCTTTGATGACTACATGT & 96 & NM_182786 \\
\hline & $\mathrm{R}$ & AGGAACCAGACAGGTCCATGTC & & \\
\hline \multirow[t]{2}{*}{ GJA1 } & $\mathrm{F}$ & GCTCCTCTCTCGCCCATGT & 100 & NM_174068 \\
\hline & $\mathrm{R}$ & TTTGCTCACTTGCTTGTTTGTTG & & \\
\hline \multirow[t]{2}{*}{ IFIT3 } & $\mathrm{F}$ & GGGTCGAGAAGCTCTCTGAGTATAGA & 69 & DW183548 \\
\hline & $\mathrm{R}$ & GCGTGAAGAAGGCAGTGAGG & & \\
\hline \multirow[t]{2}{*}{ IRF6 } & $\mathrm{F}$ & TCTGGTGACTTCACACGATCCT & 90 & NM_001076934 \\
\hline & $\mathrm{R}$ & CAGCTGAGCAACGATGTTATCC & & \\
\hline \multirow[t]{2}{*}{ ISG15 } & $\mathrm{F}$ & AGGGAGGCCCATGGATGA & 89 & NM_174366 \\
\hline & $\mathrm{R}$ & CACCCCGAAGACGTAGATTCA & & \\
\hline \multirow[t]{2}{*}{ OAS1 } & $\mathrm{F}$ & TCACAGCTCAGGGATTTCAGACT & 75 & NM_001040606 \\
\hline & $\mathrm{R}$ & TCTTTTCCCAGTAGATGCAAAGC & & \\
\hline \multirow[t]{2}{*}{ PARM1 } & $\mathrm{F}$ & CAGAATGGGCTTCAACCTTGAT & 93 & DW183724 \\
\hline & $\mathrm{R}$ & ATCACGCCTGCCTAAGAAATGA & & \\
\hline \multirow[t]{2}{*}{ PTGES } & $\mathrm{F}$ & AGACCАTCTACСССТTССТGTTC & 118 & NM_174443 \\
\hline & $\mathrm{R}$ & GCCACGGTGTGTACCATACG & & \\
\hline \multirow[t]{2}{*}{ PTGS2 } & $\mathrm{F}$ & ACCATTTGGCTACGGGAACAC & 71 & NM 174445 \\
\hline & $\mathrm{R}$ & TCATCGCCCCATTCTGGAT & & \\
\hline \multirow[t]{2}{*}{ TGFB1 } & $\mathrm{F}$ & TGCTTCAGCTCCACAGAAAAGA & 115 & NM_001166068 \\
\hline & $\mathrm{R}$ & GGCAGAAATTGGCGTGGTA & & \\
\hline \multirow[t]{2}{*}{ ZFP36L1 } & $\mathrm{F}$ & AATTTCCCCССTTTGTGTTGG & 75 & NM_001101234 \\
\hline & $\mathrm{R}$ & CATTCTCAGTCCTAGTTGTGAAAGGC & & \\
\hline
\end{tabular}

GAPDH, glyceraldehyde-3-phosphate dehydrogenase; $\mathrm{F}$, forward; R, reverse; PPIA, peptidylpropyl isomerase $\mathrm{A}$; $A K R 1 B 1$, aldo-keto reductase family 1, member $\mathrm{B} 1 ;$ ANXA2, annexin A2; CTGF, connective tissue growth factor; CXCL10, chemokine (C-X-C motif) ligand 10; CYP39A1, cytochrome P450, family 39, subfamily A, polypeptide 1; DKK1, dickkopf homologue 1; FOS, FBJ murine osteosarcoma viral oncogene homologue; GJA1, gap junction protein, $\alpha 1,43 \mathrm{kDa}$; IFIT3, interferon-induced protein with tetratricopeptide repeats 3; IRF6, interferon regulatory factor 6; ISG15, ISG15 ubiquitin-like modifier; OAS1, 2',5'-oligoadenylate synthetase 1, 40/46 kDa; PARM1, prostate androgen-regulated mucin-like protein 1; PTGES, PGE synthase; PTGS2, PG endoperoxide synthase 2; TGFB1, transforming growth factor, $\beta 1 ; Z$ PFP36L1, Zn finger protein $36, \mathrm{C} 3 \mathrm{H}$ type-like 1. 
(CO). Among these treatments, $\mathrm{P}_{4}$ and roIFNT had no effect on the gene expression levels of $A K R 1 B 1$, connective tissue growth factor $(C T G F)$, cytochrome P450, family 39, subfamily A, polypeptide 1 (CYP39A1), FBJ murine osteosarcoma viral oncogene homologue (FOS), gap junction protein, $\alpha 1$, $43 \mathrm{kDa}$ (GJA1), interferon regulatory factor 6 (IRFO), PTGES and PG endoperoxide synthase 2 (PTGS2) in either SC or EC (results not shown). In EC, the transcript levels of chemokine (C-X-C motif) ligand 10 (CXCL1O) and DKK-1 were below the detection limit as measured by the quantitative PCR technique. Significant results are shown in Fig. 1. In SC, significant increases in relative mRNA abundance were observed for CXCL1O $(P<0.05)$, interferon-induced protein with tetratricopeptide repeats 3 (IFIT3) and OAS1 $(P<0.01), I S G 15$ and prostate androgen-regulated mucin-like protein 1 (PARM1) $(P<0 \cdot 001)$ genes in cells treated with $\mathrm{P}_{4}$ and roIFNT (COPI) when compared with those treated with $\mathrm{P}_{4}$ only (COP) or with no hormone (CO) (Fig. 1(A)). There was a significant increase in the relative mRNA abundance of annexin A2 (ANXA2;P<0.05) in cells treated with $\mathrm{P}_{4}$ and roIFNT (COPI) compared with those treated with $\mathrm{P}_{4}$ only (COP). Moreover, there was a tendency for an increase in the relative mRNA abundance of DKK1 in cells treated with $\mathrm{P}_{4}$ (COP $v$. CO: $0.05<P<0 \cdot 1$ ), whereas a further increase was observed in cells exposed to $\mathrm{P}_{4}$ and roIFNT (COPI $v$. CO: $P<0.05)$. In EC, there was a significant increase in the mRNA abundance of ISG15 $(P<0.05)$, IFIT3 and OAS1 $(P<0.01)$, and PARM1 (tendency, $0.05<P<0.1$ ) in cells treated with $\mathrm{P}_{4}$ and roIFNT (COPI) compared with those not treated with hormones (CO) or $\mathrm{P}_{4}$ (COP) (Fig. 1(B)).
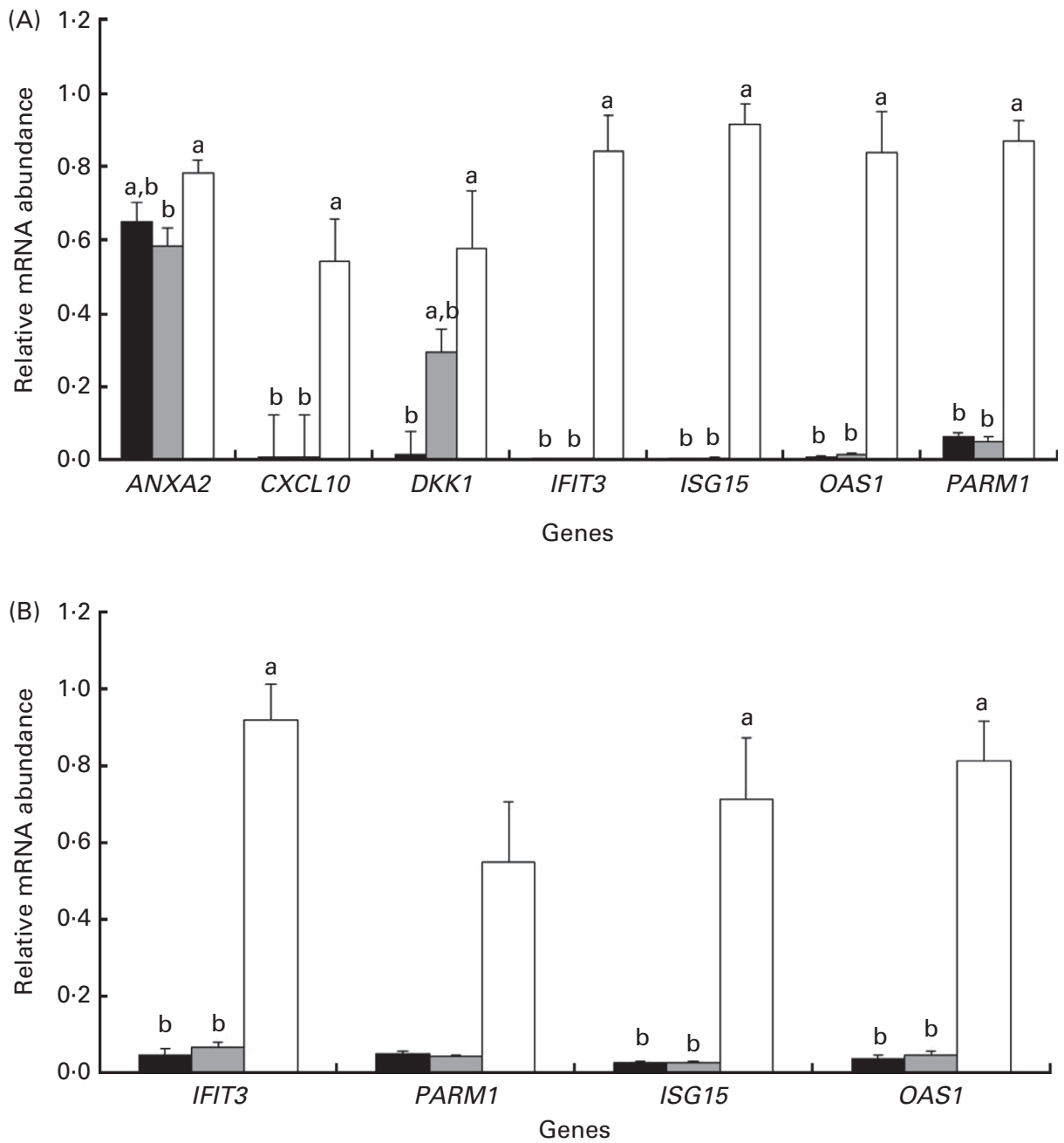

Fig. 1. Relative mRNA abundance of selected genes in primary endometrial cell cultures treated with progesterone and recombinant ovine interferon- $\tau$ (rolFNT). Genes with significant differences or tendencies in relative mRNA abundance between the three treatments are presented. Data represents relative mRNA abundance mean values with their standard errors of four cell-culture experiments performed in triplicate. ${ }^{a, b}$ Mean values with unlike letters were significantly different $(P \leq 0.05)$. The mean of all the three reference genes polyubiquitin, GAPDH (glyceraldehyde-3-phosphate dehydrogenase) and $P P I A$ (peptidylpropyl isomerase A) was used for normalisation. The hormonal treatments were as follows: CO ( $\square$ ), control cells without progesterone and rolFNT; COP ( $\square$ ), control cells treated with progesterone; COPI $(\square)$, control cells treated with progesterone and rolFNT. ANXA2, annexin A2; CXCL10, chemokine (C-X-C motif) ligand 10; $D K K 1$, dickkopf homologue 1; IFIT3, interferon-induced protein with tetratricopeptide repeats 3; ISG15, ISG15 ubiquitin-like modifier; OAS1, 2',5'-oligoadenylate synthetase 1, 40/46 kDa; PARM1, prostate androgen-regulated mucin-like protein 1. (A) SC, stromal cells and (B) EC, epithelial cells (includes luminal and glandular epithelial cells). 
Effects of different fatty acid ratios and enterolactone on the relative $m R N A$ abundance of selected genes in bovine endometrial cells

Selected genes (see Table 2) were previously identified as differentially expressed genes in the endometrial tissues of cows that were fed a $10 \%$ flaxseed supplement compared with those fed a control diet ${ }^{(26,27)}$. To identify which flaxseed component (flax oil ( $n-3)$, lignans (ENL) or both) influenced the endometrial mRNA abundance of the genes studied, different $n-6: n-3$ FA ratios and ENL concentrations were assayed in two bovine endometrial cell types (SC and EC). The global analysis of the relative mRNA abundance data of all treatments containing $\mathrm{P}_{4}$ and roIFNT (see Table 1) revealed a trend $(0.05<P<0.1)$ for an overall treatment effect for the IFIT3 gene in SC only (results not shown). Furthermore, multiple comparisons with the COPI treatment revealed that the treatment of SC with $10 \mu \mathrm{m}$-ENL (E10) decreased the mRNA abundance of IFIT3 $(P<0.05$; results not shown).

To further investigate how the different $n-6: n-3$ FA ratios modulate the mRNA abundance of selected genes in both endometrial cell types, an all-pairwise multiple comparison analysis was performed separately (Fig. 2). In SC (Fig. 2(A)), analysis of all FA ratios revealed a significant overall treatment effect for the transcript abundance of CXCL1O and IFIT3 $(P<0.05)$ and a tendency for the transcript abundance of FOS and CYP39A1 $(0.05<P<0 \cdot 1)$. Moreover, the all-pairwise multiple comparison analysis revealed that the relative mRNA abundance of FOS was the highest in cells treated with LA and ALA at a ratio of 15 (FA15), and significant differences were observed when compared with the FA0, FA1 and FA25
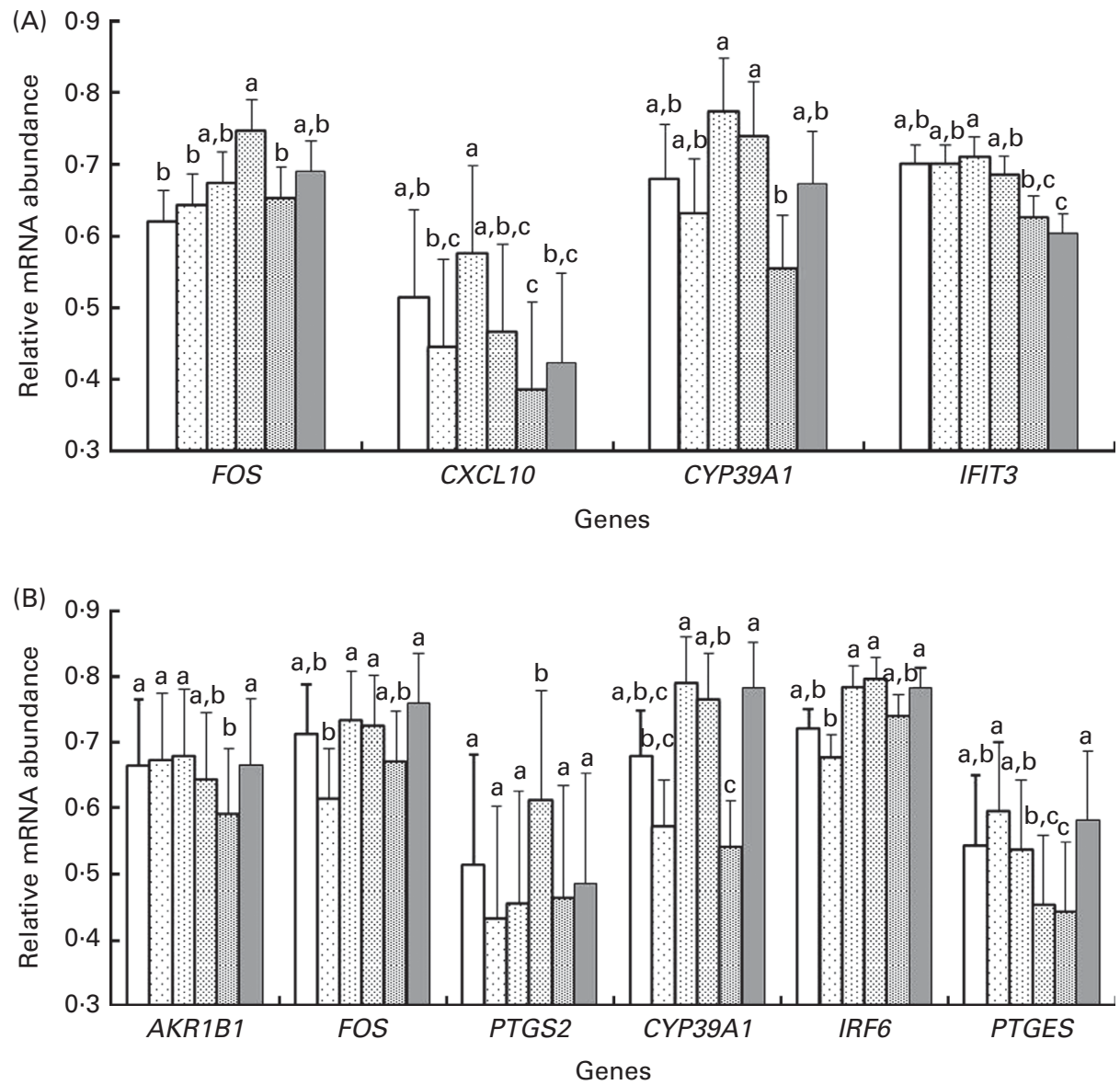

Fig. 2. Relative mRNA abundance of selected genes in bovine primary endometrial cell cultures treated with fatty acids (FA) at different ratios (linoleic acid $(\mathrm{LA}): \alpha$-linolenic acid (ALA)). Upon reaching confluence, cells were incubated for $24 \mathrm{~h}$ with appropriate treatments, followed by an additional $24 \mathrm{~h}$ of incubation in a fresh culture medium without FA (see Table 1). Genes with significant overall differences or tendencies for relative mRNA abundance between the six treatments are presented. In stromal cells (SC), a global analysis of all FA ratios revealed a significant treatment effect on the transcript abundance of CXCL10 (chemokine (C-X-C motif) ligand 10) and IFIT3 (interferon-induced protein with tetratricopeptide repeats 3$)(P<0.05)$ and a tendency for the transcript abundance of $F O S$ (FBJ murine osteosarcoma viral oncogene homologue) and CYP39A1 (cytochrome P450, family 39, subfamily A, polypeptide 1$)(0.05<P<0.1)$. In epithelial cells (EC), there was a significant overall effect of the different LA:ALA ratios on the mRNA abundance of PTGES (PGE synthase) and PTGS2 (PG endoperoxide synthase 2) $(P<0.05)$ and tendencies were observed for the mRNA abundance of AKR1B1 (aldo-keto reductase family 1, member B1), FOS, CYP39A1 and IRF6 (interferon regulatory factor 6$)(0.05<P<0.1)$. Values are means of four cell-culture experiments performed in triplicate, with their standard errors represented by vertical bars. ${ }^{\mathrm{a}, \mathrm{b}, \mathrm{c}}$ Mean values with unlike letters were significantly different $(P \leq 0.05)$. The mean of all the three reference genes polyubiquitin, GAPDH (glyceraldehyde-3-phosphate dehydrogenase) and PPIA (peptidylpropyl isomerase A) was used for normalisation. The cell treatments were as follows:

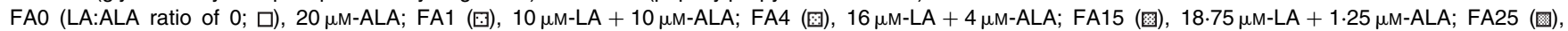
$19.23 \mu \mathrm{M}-\mathrm{LA}+0.77 \mu \mathrm{M}-\mathrm{ALA} ; \mathrm{FA} \infty$ ( $\square$ ), $20 \mu \mathrm{M}-\mathrm{LA}$. (A) SC and (B) EC (includes luminal and glandular epithelial cells). 
treatments $(P<0.05$; Fig. 2(A)). The CXCL1O and CYP39A1 transcripts responded similarly to the addition of FA at different ratios. Indeed, the highest and lowest mRNA levels of CXCL1O and CYP39A1 were observed, respectively, with the FA4 and FA25 treatments $(P<0 \cdot 05)$. The mRNA abundance of IFIT3 decreased with increasing LA:ALA ratios, and the lowest mRNA abundance was observed with the FA $\infty$ treatment, which was significantly different from the FA0, FA1, FA4 and FA15 treatments $(P<0.05)$.

In EC (Fig. 2(B)), there was an overall effect of the different LA:ALA ratios on the MRNA abundance of PTGES and PTGS2 $(P<0.05)$, and tendencies were observed for AKR1B1, FOS, $C Y P 39 A 1$ and IRFG genes $(0.05<P<0 \cdot 1)$. The two PG synthase genes $A K R 1 B 1$ and PTGES responded similarly to the addition of FA at different ratios. Indeed, these two genes had the lowest mRNA abundance in cells treated with FA25, which was significantly different from those treated with FA0, FA1, FA 4 and FA $\infty(P<0 \cdot 05)$. For PTGES, mRNA abundance was lower in cells treated with FA15 than in those treated with FA1 and FA $\infty(P<0 \cdot 05)$. The mRNA abundance of CYP39A1 was lower in cells exposed to FA25 than in those exposed to FA4, FA15 and FA $\infty(P<0 \cdot 05)$. Also, the mRNA abundance of CYP39A1 was lower in cells treated with FA1 than in those treated with FA4 and FA $\infty(P<0.05)$. The mRNA abundance of FOS and IRFC was found to be lowest in cells exposed to FA1, which was significantly different from those exposed to FA4, FA15 and FA $\infty(P<0.05)$. The mRNA abundance of PTGS2 was found to be highest in EC treated with FA15, which was significantly different from those exposed to FA0 $(P<0.05)$ and FA1, FA4, FA25 and FA $\infty(P<0 \cdot 01)$.

To determine whether ENL, alone or in combination with FA4, can modulate the relative mRNA abundance of selected genes in primary endometrial cell cultures, an additional analysis was performed according to a $3 \times 2$ factorial arrangement of treatments. Significant results are presented in Table 3. In $\mathrm{SC}$, the presence of ENL significantly decreased the mRNA abundance of AKR1B1, DKK1, IFIT3, IRFG, PTGES and ZFP36L1 and tended to reduce the mRNA abundance of OAS1 and transforming growth factor, $\beta 1$ (TGF $\beta 1$ ). Regardless of the presence or absence of FA in cell-culture media, SC that were cultured with E10 had lower mRNA abundance than those exposed to $0 \mu \mathrm{M}-\mathrm{ENL}$ for the following genes: $A K R 1 B 1$ (0.474 v. 0.544, P<0.05); DKK1 (0.430 v. 0.584, $P<0.05)$; ZFP36L1 (0.502 v. 0.668, P<0.05); IFIT3 (0.591 v. 0.777 , $P<0.01)$; IRFG (0.446 v. 0.587, P<0.05); PTGES (0.357 v. $0.542, \quad P<0.001)$. Moreover, a significant difference was observed between 10 and $1 \mu \mathrm{m}$-ENL for the mRNA abundance of $A K R 1 B 1$ ( $0.474 v \cdot 0.542, P<0.05)$. A significant interaction between FA and ENL $(P<0.05)$ was obtained for $A K R 1 B 1$,

Table 3. Effects of enterolactone (ENL), alone or in combination with a linoleic acid (LA): $\alpha$-linolenic acid (ALA) ratio of $4: 1$, on the expression of the selected genes in endometrial stromal (SC) and epithelial (EC) cells $\ddagger$

(Mean values with their standard errors)

\begin{tabular}{|c|c|c|c|c|c|c|c|c|c|c|c|}
\hline \multirow[b]{3}{*}{ Cell types } & \multirow[b]{3}{*}{ Genes } & \multicolumn{6}{|c|}{ Treatments } & \multirow[b]{3}{*}{ SEM } & \multirow{2}{*}{\multicolumn{3}{|c|}{$P$}} \\
\hline & & \multicolumn{3}{|c|}{ No FA } & \multicolumn{3}{|c|}{ FA4 } & & & & \\
\hline & & $\begin{array}{c}0 \mu \mathrm{M}-\mathrm{ENL} \\
\mathrm{COPI}\end{array}$ & $\begin{array}{c}1 \mu \mathrm{M}-\mathrm{ENL} \\
\mathrm{E} 1\end{array}$ & $\begin{array}{c}10 \mu \mathrm{M}-\mathrm{ENL} \\
\mathrm{E} 10\end{array}$ & $\begin{array}{c}0 \mu \mathrm{M}-\mathrm{ENL} \\
\mathrm{FA}\end{array}$ & $\begin{array}{c}1 \mu \mathrm{M}-\mathrm{ENL} \\
\mathrm{E} 1 \mathrm{FA}\end{array}$ & $\begin{array}{c}10 \mu \mathrm{M}-\mathrm{ENL} \\
\mathrm{E} 10 \mathrm{FA}\end{array}$ & & ENL & FA & $\mathrm{ENL} \times \mathrm{FA}$ \\
\hline \multirow[t]{9}{*}{$\mathrm{SC}$} & $A K R 1 B 1$ & 0.567 & 0.520 & 0.506 & 0.520 & 0.564 & 0.442 & 0.106 & $0.006^{*}$ & 0.204 & $0.038^{*}$ \\
\hline & $D K K 1$ & 0.578 & 0.500 & 0.412 & 0.591 & 0.434 & 0.449 & 0.124 & $0.019^{*}$ & 0.899 & 0.561 \\
\hline & IFIT3 & 0.843 & 0.634 & 0.551 & 0.712 & 0.652 & 0.632 & 0.057 & $0.008^{*}$ & 0.801 & 0.150 \\
\hline & IRF6 & 0.636 & 0.520 & 0.492 & 0.539 & 0.585 & 0.400 & 0.183 & $0.011^{*}$ & 0.249 & 0.122 \\
\hline & OAS1 & 0.839 & 0.771 & 0.704 & 0.835 & 0.768 & 0.771 & 0.076 & $0.061 \dagger$ & 0.541 & 0.593 \\
\hline & PTGES & 0.543 & 0.445 & 0.382 & 0.541 & 0.451 & 0.332 & 0.077 & $0.001^{*}$ & 0.644 & 0.758 \\
\hline & PTGS2 & 0.414 & 0.559 & 0.524 & 0.594 & 0.546 & 0.644 & 0.100 & 0.326 & $0.038^{*}$ & 0.197 \\
\hline & TGFB1 & 0.683 & 0.675 & 0.586 & 0.589 & 0.633 & 0.553 & 0.085 & $0.052 \dagger$ & $0.056 \dagger$ & 0.627 \\
\hline & ZFP36L1 & 0.686 & 0.586 & 0.475 & 0.650 & 0.657 & 0.530 & 0.101 & $0.011^{*}$ & 0.462 & 0.518 \\
\hline \multirow[t]{10}{*}{$\mathrm{EC}$} & $A N X A 2$ & 0.708 & 0.793 & 0.812 & 0.717 & 0.798 & 0.762 & 0.060 & $0.047^{\star}$ & 0.677 & 0.616 \\
\hline & CTGF & 0.739 & 0.761 & 0.788 & 0.705 & 0.696 & 0.697 & 0.068 & 0.892 & $0.097 \dagger$ & 0.809 \\
\hline & GJA1 & 0.683 & 0.764 & 0.626 & 0.675 & 0.616 & 0.527 & 0.065 & $0.074 \dagger$ & $0.055 \dagger$ & 0.387 \\
\hline & IFIT3 & 0.918 & 0.848 & 0.686 & 0.789 & 0.686 & 0.673 & 0.062 & $0.003^{\star}$ & $0.009^{*}$ & 0.198 \\
\hline & ISG15 & 0.714 & 0.759 & 0.663 & 0.572 & 0.616 & 0.621 & 0.082 & 0.715 & $0.052 \dagger$ & 0.669 \\
\hline & OAS1 & 0.812 & 0.796 & 0.761 & 0.751 & 0.688 & 0.678 & 0.080 & 0.195 & $0.007^{\star}$ & 0.780 \\
\hline & PARM1 & 0.549 & 0.648 & 0.616 & 0.479 & 0.572 & 0.500 & 0.122 & 0.184 & $0.047^{\star}$ & 0.882 \\
\hline & PTGS2 & 0.401 & 0.602 & 0.418 & 0.457 & 0.490 & 0.422 & 0.164 & $0.004^{*}$ & 0.543 & $0.072 \dagger$ \\
\hline & TGFB1 & 0.846 & 0.794 & 0.761 & 0.728 & 0.718 & 0.720 & 0.085 & 0.358 & $0.008^{*}$ & 0.493 \\
\hline & ZFP36L1 & 0.759 & 0.846 & 0.862 & 0.769 & 0.816 & 0.788 & 0.047 & $0.087 \dagger$ & 0.231 & 0.409 \\
\hline
\end{tabular}

FA, fatty acids; COPI, control cells treated with progesterone and recombinant ovine interferon- $\tau$; E1, $1 \mu \mathrm{M}$-ENL; E10, $10 \mu \mathrm{M}$-ENL; FA4, $16 \mu \mathrm{M}-\mathrm{LA}: 4 \mu \mathrm{M}-\mathrm{ALA}$ ratio of 4; E1FA, $1 \mu \mathrm{M}-\mathrm{ENL}+\mathrm{FA4}$; E10FA, $10 \mu \mathrm{M}-\mathrm{ENL}+\mathrm{FA4}$; AKR1B1, aldo-keto reductase family 1, member B1; DKK1, dickkopf homologue 1; IFIT3, interferon-induced protein with tetratricopeptide repeats 3 ; IRF6, interferon regulatory factor 6; OAS1, 2',5'-oligoadenylate synthetase 1, 40/46 kDa; PTGES, PGE synthase; PTGS2, PG endoperoxide synthase 2; TGFB1, transforming growth factor, $\beta 1$; ZFP36L1; Zn finger protein 36, C3H type-like 1; ANXA2, annexin A2; CTGF, connective tissue growth factor; GJA1, gap junction protein, $\alpha 1,43 \mathrm{kDa}$; ISG15, ISG15 ubiquitin-like modifier; PARM1, prostate androgen-regulated mucin-like protein 1.

${ }^{*} P<0.05$.

$\dagger 0.05<P<0.1$.

$\ddagger$ Results were obtained from four cell-culture experiments performed in triplicate and compared with a $3 \times 2$ factorial arrangement. All culture media contained 10 nM-progesterone and $50 \mathrm{~nm}$-recombinant ovine interferon- $\tau$. 
with the lowest mRNA abundance being observed when E10 was combined with $20 \mu \mathrm{m}-\mathrm{FA} 4$. There was a significant effect of FA on the mRNA abundance of PTGS $2(P<0.038)$, with higher levels being observed in cells treated with FA4 than in those with no added fat $(0.595 v .0 .499,0.05<P<0.1)$. Finally, there was a trend observed for the effect of FA on the mRNA abundance of TGF $\beta 1(0.05<P<0.1)$, with higher mRNA levels being observed in SC that had no added fat compared with those exposed to $20 \mu \mathrm{M}$-FA4

In EC (Table 3), the presence of ENL in culture media significantly increased the mRNA abundance of ANXA2 $(P<0.05)$ and tended to increase the mRNA abundance of ZFP36L1. In contrast, the transcript abundance of IFIT3 significantly decreased $(P<0 \cdot 01)$ and the mRNA abundance of GJA1 tended to decrease when ENL was included in cell-culture media. When comparing the different ENL concentrations, the E10 treatment decreased the mRNA abundance of IFIT3 when compared with the $0 \mu \mathrm{M}$-ENL treatment $(0.679 v$. 0.853, $P<0.01)$. There was a tendency for an ENL $\times$ FA interaction for the mRNA abundance of PTGS2 in EC, with the highest level being observed for the E1 treatment, without added FA. Moreover, the mRNA levels of PTGS2 for the E1 treatment (independently of FA) were higher than those found for the E0 $(0.546 v .0 .429, P=0.01)$ and E10 (0.546 $v .0 .420, P<0.01)$ treatments. The addition of $20 \mu \mathrm{M}-\mathrm{FA} 4$ in culture media significantly decreased the mRNA abundance
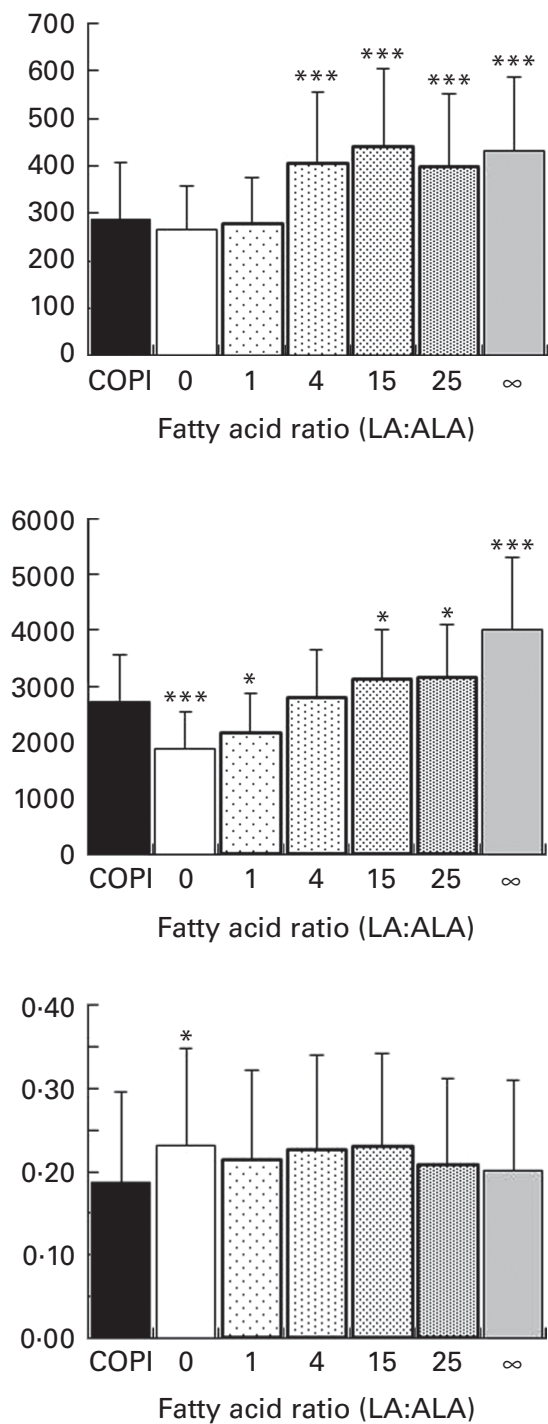

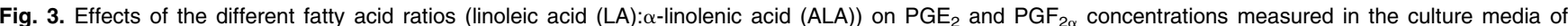
stromal (SC; left panels) and epithelial (EC; right panels) endometrial cells. Upon reaching confluence, cells were incubated for $24 \mathrm{~h}$ with appropriate treatments, followed by an additional $24 \mathrm{~h}$ of incubation in fresh culture medium without fatty acids (see Table 1 ). Values are means of four cell-culture experiments performed in duplicate, with their standard errors represented by vertical bars. PG data were analysed using Friedman's test on rank-transformed data followed by multiple comparisons of each treatment with the control cells treated with progesterone and recombinant ovine interferon- $\tau$ containing no added fatty acids (COPI). Mean value was significantly different from that of the COPI treatment: ${ }^{\star} P \leq 0.05,{ }^{\star \star} P \leq 0.01,{ }^{\star \star \star} P \leq 0.001$. When performing a global analysis of $P G$ concentration data, there was an overall treatment effect for $\mathrm{PGE}_{2}$ and $\mathrm{PGF}_{2 \alpha}$ concentrations in $\mathrm{SC}$ and $\mathrm{EC}$ (includes luminal and glandular epithelial cells) $(P<0.001)$ and for the $\mathrm{PGE}_{2}: \mathrm{PGF}_{2 \alpha}$ ratio in EC $(P<0.01)$. Fatty acid ratios: $0,20 \mu \mathrm{M}-\mathrm{ALA} ; 1,10 \mu \mathrm{M}-\mathrm{LA}+10 \mu \mathrm{M}-\mathrm{ALA} ; 4,16 \mu \mathrm{M}-\mathrm{LA}+4 \mu \mathrm{M}-\mathrm{ALA} ; 15,18.75 \mu \mathrm{M}-\mathrm{LA}+1.25 \mu \mathrm{M}-\mathrm{ALA}$; $25,19 \cdot 23 \mu \mathrm{M}-\mathrm{LA}+0.77 \mu \mathrm{M}-\mathrm{ALA} ; \infty, 20 \mu \mathrm{M}-\mathrm{LA}$. 
of PARM1 $(P<0.05)$, IFIT3 $(P<0.01)$, OAS1 $(P<0.01)$ and TGFB1 $(P<0.001)$, and tended to reduce the mRNA abundance of CTGF, GJA1 and ISG15 (0.05 $<P<0 \cdot 1)$.

\section{Effects of different fatty acid ratios and enterolactone on $P G$ concentrations in bovine endometrial cells}

In addition to the relative mRNA abundance of selected genes, $\mathrm{PGE}_{2}$ and $\mathrm{PGF}_{2 \alpha}$ concentrations were assessed in the culture media of SC and EC, with series 2 PG playing a key role in the embryo implantation process. The global analysis of $\mathrm{PGE}_{2}$ and $\mathrm{PGF}_{2 \alpha}$ concentrations for all the treatments (thirteen experimental treatments; see Table 1) revealed an overall treatment effect in SC and EC $(P<0.001)$ and an overall treatment effect for the $\mathrm{PGE}_{2}: \mathrm{PGF}_{2 \alpha}$ ratio in EC only $(P<0 \cdot 01)$ (results not shown). Multiple comparisons (Fig. 3) then revealed that the treatment of SC with FA4 $(P<0 \cdot 001)$, FA15 $(P<0.05)$ and FA $\infty(P<0.01)$ significantly increased $\mathrm{PGE}_{2}$ concentrations when compared with those that were not treated with LA and/or ALA (COPI). Significant increases in PGF $_{2 \alpha}$ concentrations were observed when SC were treated with FA4 (v. COPI, $P<0 \cdot 01)$ and FA $\infty$ ( $v$. COPI, $P<0 \cdot 01$ ), whereas the FA0 treatment decreased $\mathrm{PGF}_{2 \alpha}$ concentrations (FA0 $v$. COPI, $P<0 \cdot 01)$. In EC, $\mathrm{PGE}_{2}$ concentrations increased with the FA4, FA15, FA25 and FA $\infty$ treatments when compared with the COPI treatment $(P<0 \cdot 001)$. The FA15 ( $v$. COPI, $P<0.05$ ), FA25 ( $v$. COPI, $P<0.05$ ) and FA $\infty$ ( $v$. COPI, $P<0.001)$ treatments all increased $\mathrm{PGF}_{2 \alpha}$ concentrations. On the contrary, EC treated with FA0 ( $v$. COPI, $P<0 \cdot 001$ ) and FA1 ( $v$. COPI, $P<0.05)$ significantly decreased $\mathrm{PGF}_{2 \alpha}$ concentrations. Finally, the $\mathrm{PGE}_{2}: \mathrm{PGF}_{2 \alpha}$ ratio was increased with the FA0 treatment ( $v$. COPI, $P<0 \cdot 01)$ in EC only.

To further investigate how the different LA:ALA ratios affect $\mathrm{PGE}_{2}$ and $\mathrm{PGF}_{2 \alpha}$ secretion in both endometrial cell types, an all-pairwise multiple comparison analysis was performed separately (Fig. 4). In the culture media of $\mathrm{SC}, \mathrm{PGE}_{2}$ and $\mathrm{PGF}_{2 \alpha}$ concentrations were affected in the same way by the different LA:ALA ratios, with lower PG concentrations being observed in cells treated with LA and ALA at the ratios of 0 and 1 when compared with those treated with FA at all the other ratios $(P<0 \cdot 05)$. In $\mathrm{SC}$, no significant difference in the $\mathrm{PGE}_{2}$ : $\mathrm{PGF}_{2 \alpha}$ ratio was found among the different FA ratios. In EC, the lowest $\mathrm{PGE}_{2}$ and $\mathrm{PGF}_{2 \alpha}$ concentrations were found in cells treated with LA and ALA at the ratios of 0 and 1 , which were significantly different from those treated with FA at all the other ratios $(P<0 \cdot 05)$. $\mathrm{PGF}_{2 \alpha}$ concentrations measured in the culture media of EC increased gradually with increasing LA:ALA ratios. The $\mathrm{PGE}_{2}: \mathrm{PGF}_{2 \alpha}$ ratios were not affected by the treatment with LA and ALA at the different ratios.

To determine whether ENL, alone or in combination with FA4, can modulate $\mathrm{PGE}_{2}$ and $\mathrm{PGF}_{2 \alpha}$ secretion in primary endometrial cell cultures, an additional analysis was performed according to a $3 \times 2$ factorial arrangement of treatments (Table 4). In SC, there was an overall effect of ENL and $\mathrm{FA}$ on $\mathrm{PGE}_{2}(P<0.05)$ and $\mathrm{PGF}_{2 \alpha}(\mathrm{ENL}, P<0 \cdot 01$ FA, $P<0.05)$ concentrations, whereas no effect on the $\mathrm{PGE}_{2}$ : $\mathrm{PGF}_{2 \alpha}$ ratio was observed. When performing an all-pairwise analysis on $\mathrm{PGE}_{2}$ concentrations, there was a tendency for lower $\mathrm{PGE}_{2}$ concentrations in cells treated with E10 compared with those treated with $0 \mu \mathrm{m}-\mathrm{ENL}(598.16 v .841 .57 \mathrm{pg} / \mathrm{ml}$, $0.05<P<0.1) \quad$ or $1 \mu \mathrm{M}-\mathrm{ENL} \quad(598.16 \quad v . \quad 708.20 \mathrm{pg} / \mathrm{ml}$,
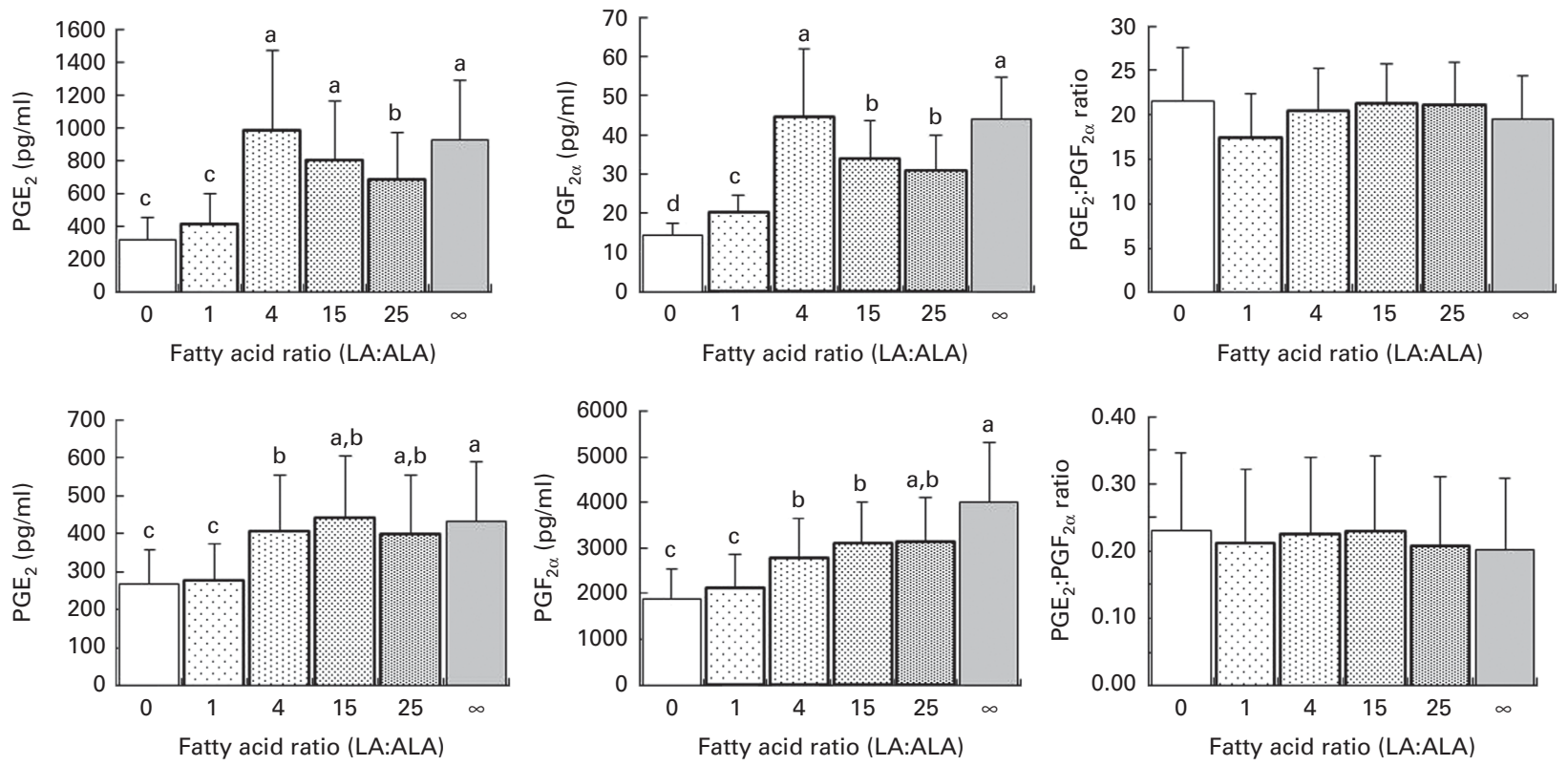

Fig. 4. Effects of the different fatty acid ratios (linoleic acid (LA): $\alpha$-linolenic acid (ALA)) on $\mathrm{PGE}_{2}$ and PGF $\mathrm{P}_{2 \alpha}$ secretion in stromal (SC; upper panels) and epithelial (EC lower panels) (includes luminal and glandular epithelial cells) endometrial cells. Upon reaching confluence, cells were incubated for $24 \mathrm{~h}$ with appropriate treatments, followed by an additional $24 \mathrm{~h}$ of incubation in fresh culture medium without fatty acids (see Table 1 ). Values are means of four cell-culture experiments performed in duplicate, with their standard errors represented by vertical bars. PG data were analysed using Friedman's test on rank-transformed data followed by all-pairwise multiple comparisons. Mean values with unlike letters were significantly different $(P \leq 0.05)$. The cell treatments were as follows: FA0 (LA:ALA ratio of 0$)$, $20 \mu M-A L A$; FA1, $10 \mu \mathrm{M}-\mathrm{LA}+10 \mu \mathrm{M}-\mathrm{ALA}$; FA4, $16 \mu \mathrm{M}-\mathrm{LA}+4 \mu \mathrm{M}-\mathrm{ALA} ; \mathrm{FA} 15,18.75 \mu \mathrm{M}-\mathrm{LA}+1.25 \mu \mathrm{M}-\mathrm{ALA} ; \mathrm{FA} 25,19 \cdot 23 \mu \mathrm{M}-\mathrm{LA}+$ 0.77 $\mu \mathrm{M}-\mathrm{ALA} ; \mathrm{FA} \infty, 20 \mu \mathrm{M}-\mathrm{LA}$. 
$0.05<P<0 \cdot 1)$. Similarly, lower $\mathrm{PGF}_{2 \alpha}$ concentrations were found in SC treated with E10 compared with those treated with $0 \mu \mathrm{M}$-ENL $(23.58 v .39 \cdot 31 \mathrm{pg} / \mathrm{ml}, P<0.01)$ or with $1 \mu \mathrm{M}-$ ENL (tendency, $23.58 v .30 .23,0.05<P<0.1$ ). For both $\mathrm{PGE}_{2}$ and $\mathrm{PGF}_{2 \alpha}$ concentrations, the interaction between ENL and FA tended to be significant $(0.05<P<0 \cdot 1)$.

In EC, there was an overall effect of ENL and FA on $\mathrm{PGE}_{2}$ (ENL, $\quad P<0.05 ; \quad \mathrm{FA}, \quad P<0.01$ ) and $\mathrm{PGF}_{2 \alpha}$ (ENL and FA, $P<0.01)$ concentrations and an effect of $\mathrm{FA}$ on the $\mathrm{PGE}_{2}$ : $\mathrm{PGF}_{2 \alpha}$ ratio $(P<0 \cdot 001)$. There was a significant effect of the $\mathrm{ENL} \times \mathrm{FA}$ interaction $(P<0 \cdot 01)$ on $\mathrm{PGF}_{2 \alpha}$ concentrations, with the lowest concentration being observed when E10 was combined with FA (FA4). The all-pairwise analysis for the ENL factor revealed lower $\mathrm{PGE}_{2}$ concentrations in cells treated with E10 compared with those treated with $1 \mu \mathrm{M}$-ENL (265.00 v. $354.54 \mathrm{pg} / \mathrm{ml}, P<0.05$ ) or $0 \mu \mathrm{M}-\mathrm{ENL}$ (tendency: $265.00 v$. $346.57 \mathrm{pg} / \mathrm{ml}, 0.05<P<0.1)$. The lowest $\mathrm{PGF}_{2 \alpha}$ concentrations were obtained with the addition of E10 compared with the treatments with $0 \mu \mathrm{M}-\mathrm{ENL}(2200 \cdot 21 v .2764 \cdot 70 \mathrm{pg} / \mathrm{ml}$, $P<0 \cdot 01)$ and $1 \mu \mathrm{M}-\mathrm{ENL}(2200 \cdot 21$ v. $3074.96 \mathrm{pg} / \mathrm{ml}, P<0 \cdot 01)$. The presence of FA (FA4) in cell-culture media significantly increased $\mathrm{PGE}_{2}$ concentrations $(P<0 \cdot 01)$ and the $\mathrm{PGE}_{2}: \mathrm{PGF}_{2 \alpha}$ ratio $(P=0 \cdot 01)$, whereas $\mathrm{PGF}_{2 \alpha}$ concentrations were decreased when both ENL and FA were present.

\section{Discussion}

The present study aimed to enhance the understanding on how transcription levels of selected genes and series 2 PG secretion vary under the treatment of LA and ALA at different ratios and/or ENL concentrations in bovine endometrial cells. Genes that were selected in the present study were previously identified as endometrial transcripts differentially expressed at day 17 of pregnancy, when dairy cows were fed $10 \%$ flaxseed in the diet ${ }^{(26,27)}$. Moreover, they were selected based on their known or suspected roles in embryo survival and PG synthesis.

In vivo, the bovine elongating conceptus secretes IFNT to signal its presence to the endometrium, and $\mathrm{P}_{4}$ is a pregnancy hormone that plays a key role in the remodelling of the endometrium during the peri-implantation period $^{(3,29)}$. To mimic the peri-implantation period in the present in vitro model, endometrial cultured cells were exposed to $\mathrm{P}_{4}$ and roIFNT. The addition of $\mathrm{P}_{4}$ alone had little effect on the mRNA abundance of the genes studied in SC and EC. However, the addition of $\mathrm{P}_{4}$ and roIFNT (COPI) successfully induced the expression of several genes in both cell types. In accordance with the present results, it was previously observed that early pregnancy and/or IFNT can induce the transcription levels of $C X C L 1 O^{(48)}, D K K 1^{(24)}, I F I T 3^{(49)}, I S G 15^{(50)}$ and $O A S 1^{(51)}$ in the ruminant endometrium. Therefore, these similarities validate our in vitro cell-culture system. In the present study, we observed a modest increase in the mRNA abundance of $A N X A 2$ with the addition of $\mathrm{P}_{4}$ and roIFNT (COPI). This gene is considered as a positive regulator of invasive processes during the peri-implantation period ${ }^{(23)}$. However, embryo implantation in cows is non-invasive ${ }^{(23)}$, which may explain the modest up-regulation of ANXA2 mRNA in SC 
treated with the two hormones. Interestingly, we report for the first time the induction of the PARM1 transcript when both $\mathrm{P}_{4}$ and roIFNT are added to endometrial cells. This gene encodes for a mucin-like type I transmembrane protein that increases cell proliferation and whose expression is androgen-regulated $^{(52)}$. More recently, PARM1 was identified in the rat ovary where it acts as a regulator of the catabolic conversion of $\mathrm{P}_{4}$ to $5 \alpha$-pregnanediol ${ }^{(53)}$. The observed up-regulation of the PARM1 transcript with the addition of $\mathrm{P}_{4}$ and roIFNT suggests a putative role for PARM1 in the establishment of early pregnancy in cattle.

In the present primary endometrial cell-culture system, we observed that the different LA:ALA ratios and/or ENL concentrations affected the transcript abundance of selected genes and series 2 PG concentrations in culture media. Moreover, we reported that the SC response to the treatments differed from the EC response, thus suggesting that mechanisms influencing gene expression and PG secretion are regulated differently in those two cell types. In accordance with the present results, Xiao et al. ${ }^{(54)}$ also observed a different regulation of PG synthesis in bovine EC and SC when steroid hormones were added to the cell-culture medium. In the bovine endometrium, SC and EC have a different morphology and present different functions ${ }^{(32)}$, which may explain the observed differences in mRNA abundance and series 2 PG concentrations. For example, it has been demonstrated earlier that $\mathrm{PGE}_{2}$ is mainly produced by SC, while EC secrete higher levels of $\mathrm{PGF}_{2 \alpha}^{(32)}$. Similar findings are reported in the present study. Herein we used SC and EC monocultures in order to investigate how these distinct endometrial cell types are affected by different LA:ALA ratios and/or ENL concentrations. This cell-culture system does not allow interactions between cell types, and we recognise that different cellular responses to the treatments may be observed in co-cultures of SC and EC. Ulbrich et al. ${ }^{(55)}$ previously reported that bovine endometrial SC are needed for the formation of tight junctions in endometrial EC. Moreover, modifications in cell proliferation, transepithelial resistance and cytokine secretion were observed when SC were co-cultured with human or mouse endometrial $\mathrm{EC}^{(37,56)}$. In contrast, there was no difference between bovine endometrial epithelial monocultures and co-cultures with SC for the accumulation of PGE or PGF in response to oxytocin and $\mathrm{AA}^{(39)}$. Additional studies are required to determine whether co-cultures of SC and EC would respond differently to the treatment with LA and ALA at different ratios and/or ENL concentrations.

The in vitro culture approach used in the present study was based on previous experiments where FA were given for $24 \mathrm{~h}$ in BEND cells ${ }^{(11,40)}$ or fed to cows for 4 weeks ${ }^{(57)}$, followed by in vitro tissue or cell culture with FA free culture media for up to 42 (tissue culture) or $6 \mathrm{~h}$ (BEND cells). Other studies have used alternative approaches where FA was included in culture media until measurements were performed ${ }^{(58,59)}$. Therefore, it would be of interest to investigate whether keeping FA in culture media throughout the whole in vitro experiments would result in different outcomes.

To the best of our knowledge, the present study is the first to evaluate the direct effects of different LA:ALA ratios on series 2 PG concentrations and gene expression in bovine endometrial primary cell cultures. The results show that transcript levels of selected genes were affected by the different LA:ALA ratios. Moreover, when considering only the three physiologically observed ratios (FA4, FA15 and FA25), many of these genes showed decreased mRNA abundance with increasing $n-6: n-3$ ratios in both cell types. FA4 corresponds to the observed circulating FA ratio when dairy cows are fed a diet containing 10\% flaxseed (rich in ALA). Interestingly, this ratio showed higher mRNA abundance of CXCL1O, CYP39A1 and IFIT3 in SC and of AKR1B1, CYP39A1 and PTGES in EC when compared with FA25, which mimics cows fed $10 \%$ sunflower seeds (rich in LA). The AKR1B1 and PTGES genes are coding for enzymes involved in the synthesis of $\mathrm{PGF}_{2 \alpha}$ and $\mathrm{PGE}_{2}$, respectively. An up-regulation of the AKR1B1 gene may also lead to higher levels of series 3 PG at the expense of series 2 PG when $n$-3 FA levels increase $^{(60)}$, which may favour embryo survival. Moreover, an up-regulation of the mRNA levels of PTGES is desirable for embryo survival since $\mathrm{PGE}_{2}{ }^{(5-7)}$ has known positive effects on uterine receptivity during the peri-implantation period $^{(5-7)}$. CXCL1O ${ }^{(48)}$ and IFIT3 ${ }^{(49)}$ are up-regulated during early pregnancy in response to embryo IFNT signal, and in the ovine endometrium, CXCL1O is involved in the redistribution of immune cells that favours conceptus implantation $^{(61)}$. Therefore, the up-regulation of CXCL1O and IFIT3 mRNA may be beneficial for embryo implantation and survival. The CYP39A1 gene encodes for a steroid hydroxylase, which prevents prolonged and inappropriate exposure to oestrogen in mice ${ }^{(62)}$. Because oestrogen levels must stay low during early pregnancy ${ }^{(63)}$, an up-regulation of CYP39A1 would favour embryo survival. Collectively, the above-mentioned results suggest that lower $n-6: n-3$ FA ratios contribute to an increase in the transcript abundance of genes that have positive effects on uterine receptivity and implantation.

High LA:ALA ratios increased $\mathrm{PGE}_{2}$ and $\mathrm{PGF}_{2 \alpha}$ concentrations both in SC and EC culture media compared with control cells that were not exposed to LA and/or ALA (COPI). Moreover, the all-pairwise multiple comparisons revealed that $\mathrm{PGF}_{2 \alpha}$ and $\mathrm{PGE}_{2}$ concentrations increased with greater LA:ALA ratios in EC, which is consistent with a previous study with BEND cells, where increasing LA:EPA ratios increases $\mathrm{PGF}_{2 \alpha}$ secretion ${ }^{(40)}$. In SC, PG concentrations were affected by the different LA:ALA ratios, with $\mathrm{PGE}_{2}$ and $\mathrm{PGF}_{2 \alpha}$ concentrations being higher at FA4 (rich in $n$-3) than at FA25 (rich in $n$-6). An increase in the synthesis and secretion of $\mathrm{PGF}_{2 \alpha}$ in SC is not desirable for embryo survival because of its luteolytic properties ${ }^{(64)}$. However, the contribution of $\mathrm{PGF}_{2 \alpha}$ secretion in $\mathrm{SC}$ to the total endometrial $\mathrm{PGF}_{2 \alpha}$ secretion is expected to be limited since $\mathrm{PGF}_{2 \alpha}$ secretion is much lower in $\mathrm{SC}$ than in $\mathrm{EC}^{(32)}$. In contrast, increased $\mathrm{PGE}_{2}$ secretion in SC would favour embryo implantation based on its positive effect on uterine receptivity ${ }^{(5)}$.

Flaxseed is rich in plant lignans that are mainly converted into the mammalian lignans ENL and enterodiol under the action of the cow's ruminal and intestinal microbiota ${ }^{(21,65)}$ Mammalian lignans are absorbed from the intestine, and most of them are conjugated to glucuronides by specific 
enzymes in the intestinal wall and liver ${ }^{(66)}$. In dairy cows, most of the metabolism of flax lignans occurs in the rumen ${ }^{(21)}$ and, ENL is the main lignan metabolite found in goat serum ${ }^{(67)}$. Plant and mammalian lignans possess antioxidant activities ${ }^{(68)}$ and can act as phyto-oestrogens ${ }^{(22)}$, which may explain, at least in part, the reproductive benefits observed when flaxseed is fed to cows ${ }^{(69)}$. However, the effects of lignans on reproductive functions have been poorly explored so far. In the present study, we show for the first time that the presence of ENL modulates series 2 PG secretion in EC and SC as well as the mRNA abundance of genes known or suspected to play a role in uterine receptivity and conceptus implantation. Indeed, in both cell types, the addition of ENL decreased $\mathrm{PGE}_{2}$ and $\mathrm{PGF}_{2 \alpha}$ concentrations in culture media. Moreover, the greatest reductions in $\mathrm{PGF}_{2 \alpha}$ concentrations were observed in EC when FA (FA4) was combined with ENL. However, the present results demonstrate that the addition of ENL has no effect on the $\mathrm{PGE}_{2}: \mathrm{PGF}_{2 \alpha}$ ratio, and that the presence of FA4 alone seems to be sufficient to increase the $\mathrm{PGE}_{2}: \mathrm{PGF}_{2 \alpha}$ ratio in EC. Petit et al. ${ }^{(69)}$ observed a higher PGE metabolite:13,14dihydro-15-keto-PGF ${ }_{2 \alpha}$ ratio in the uterine flushes of nonpregnant cows fed with $9 \cdot 1 \%$ flaxseed in the diet (which corresponds to the FA4 treatment used in the present study) when compared with those fed the control diet (no added fat), thus showing that ALA can increase the $\mathrm{PGE}_{2}: \mathrm{PGF}_{2 \alpha}$ ratio in vivo. The increase in the $\mathrm{PGE}_{2}: \mathrm{PGF}_{2 \alpha}$ ratio in $\mathrm{EC}$ might protect the CL against luteolysis and help in preparing the endometrium for implantation. However, further work is required to determine which of the following factors contribute the most in maintaining the $\mathrm{CL}$ and in uterine receptivity: $\mathrm{PGE}_{2}$ and $\mathrm{PGF}_{2 \alpha}$ secretion or the $\mathrm{PGE}_{2}: \mathrm{PGF}_{2 \alpha}$ ratio.

Among the selected genes, IFIT3, DKK1 and IRF6 ${ }^{(24,70)}$ are known interferon-stimulated genes whose expression increase in the ruminant endometrium during early pregnancy. The decreases observed in the mRNA levels of IFIT3, DKK1 and IRFG in SC and in the transcript levels of IFIT3 in EC when ENL was added to the culture medium may, therefore, negatively affect uterine receptivity. ANXA2 is a gene involved in the positive regulation of invasive growth ${ }^{(23)}$, and in the present study, the transcript levels of $A N X A 2$ were up-regulated in EC by the addition of ENL. However, because implantation in the cow is a non-invasive process, an up-regulation of the mRNA abundance of $A N X A 2$ would not necessarily improve embryo survival. It has earlier been reported that the gene expression of ZFP36L1 is essential to embryo survival ${ }^{(31,71)}$. This gene is implicated in the post-transcriptional control of gene expression and is a negative regulator of the gene activity of vascular endothelial growth factor-A $(V E G F A)^{(71)}$. Here, we observed a down-regulation of the transcript levels of ZFP36L1 in SC with the addition of ENL. Further work is needed before being able to determine the physiological impact of the decreased expression of ZFP36L1.

Among the genes that were modulated by ENL, three code for enzymes involved in the synthesis of $\mathrm{PG}^{(5)}$, which are as follows: AKR1B1, known as the primary enzyme responsible for $\mathrm{PGF}_{2 \alpha}$ production ${ }^{(72)}$; PTGES previously identified as the main enzyme responsible for the synthesis of $\mathrm{PGE}_{2}{ }^{(73)}$; PTGS2 that convert AA to PGH2, a common precursor of
$\mathrm{PGE}_{2}$ and $\mathrm{PGF}_{2 \alpha}^{(34,73)}$. Interestingly, we reported that mRNA levels of AKR1B1 and PTGES, but not PTGS2, were decreased in SC with the addition of ENL, which was associated with lower $\mathrm{PGF}_{2 \alpha}$ and $\mathrm{PGE}_{2}$ concentrations. This suggests that ENL may reduce the secretion of $\mathrm{PGE}_{2}$ and $\mathrm{PGF}_{2 \alpha}$ by modifying the transcription levels of PTGES and AKR1B1 genes in endometrial SC. Further work is needed to determine the reasons why mRNA levels of AKR1B1 and PTGES were not affected by ENL in EC despite the fact that ENL decreased the secretion of $\mathrm{PGE}_{2}$ and $\mathrm{PGF}_{2 \alpha}$. The mRNA abundance of PTGS2 was higher in SC treated with FA4, which was associated with increases in $\mathrm{PGF}_{2 \alpha}$ and $\mathrm{PGE}_{2}$ concentrations. Similar increases in the mRNA abundance of PTGS2 were observed with the addition of ALA and AA, and in $\mathrm{PGF}_{2 \alpha}$ and $\mathrm{PGE}_{2}$ concentrations with the addition of ALA and stearidonic acid to ovine endometrial cells ${ }^{(59)}$. Interestingly, Caldari-Torres et $a l .{ }^{(40)}$ previously reported an increase in the mRNA abundance of PTGS2 in BEND cells treated with increasing LA:EPA ratios, and this was accompanied by similar increases in $\mathrm{PGF}_{2 \alpha}$ secretion. Moreover, in primary bovine endometrium EC, AA-induced $\mathrm{PGF}_{2 \alpha}$ and $\mathrm{PGE}_{2}$ secretion was preceded by increases in the protein levels of PTGS2 ${ }^{(74)}$. However, in BEND cells, EPA reduced and AA increased the synthesis of

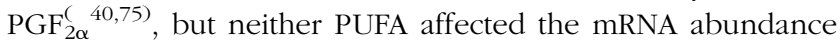
of PTGS2 ${ }^{(11)}$. In the absence of FA, the addition of ENL to EC affected the mRNA abundance of PTGS2, which followed the concentration profiles of $\mathrm{PGF}_{2 \alpha}$ and $\mathrm{PGE}_{2}$. It remains to be determined why the observed association between the mRNA levels of PTGS2 and series 2 PG concentrations is lost with the addition of FA to EC. The absence of a concordance between the mRNA levels of AKR1B1, PTGES and PTGS2 and series 2 PG concentrations does not rule out the possibility of post-translational alteration of PG synthesis enzymes by ENL and/or FA that may affect the secretion of PG.

Among the different mechanisms that have been suggested for explaining how $n-3$ and $n-6$ FA modulate series 2 PG secretion in endometrial cells, one indicates the possible inhibition of PTGS2 enzyme activity by EPA, ALA and LA, previously identified as PTGS2 inhibitors ${ }^{(76)}$. However, this mechanism is unlikely because in the present study, $\mathrm{PGE}_{2}$ and $\mathrm{PGF}_{2 \alpha}$ secretion was found to increase in EC treated with increasing LA:ALA ratios. In the present study, the lowest $\mathrm{PGE}_{2}$ and $\mathrm{PGF}_{2 \alpha}$ concentrations were observed with the lowest LA:ALA ratios (i.e. high in $n$-3), whereas the highest $\mathrm{PGE}_{2}$ and $\mathrm{PGF}_{2 \alpha}$ concentrations were obtained with high LA:ALA ratios (i.e. high in $n$-6). A possible competition between $n$ - 3 and $n-6$ FA for enzymes involved in the desaturation and elongation of long-chain FA or those involved in the synthesis of PG may explain how $n-3$ and $n-6$ FA modulate $\mathrm{PGE}_{2}$ and $\mathrm{PGF}_{2 \alpha}$ concentrations ${ }^{(60,64)}$. According to this last proposed mechanism, increased $n-3$ FA would favour the production of series 3 PG at the expense of series 2 PG. Although we found lower $\mathrm{PGE}_{2}$ and $\mathrm{PGF}_{2 \alpha}$ secretion with higher $n-3 \mathrm{FA}$, it remains to be determined whether this is accompanied with increases in series $3 \mathrm{PG}$.

In conclusion, the present results demonstrate that the addition of LA and ALA at different ratios and ENL can affect the mRNA abundance of the genes studied and $\mathrm{PGE}_{2}$ and 
$\mathrm{PGF}_{2 \alpha}$ concentrations in primary bovine endometrial cells, with different effects being observed in EC and SC. The FA4 treatment, which corresponded to the observed circulating ratio when cows were fed a diet containing $10 \%$ flaxseed, increased the mRNA abundance of genes that have positive effects on uterine receptivity and implantation, when compared with the FA25 treatment (rich in LA). This suggests that flax oil (rich in ALA) alone can modulate the transcript abundance of genes known to have beneficial effects on the fertility of dairy cows. The combination of ENL with FA (FA4) resulted in the greatest reduction in $\mathrm{PGF}_{2 \alpha}$ concentrations in both cell types, suggesting that feeding flaxseed to dairy cows would have a greater impact on the reduction in $\mathrm{PGF}_{2 \alpha}$ secretion than giving flax oil (rich in ALA) or flax meal (rich in lignans) alone. A decrease in endometrial $\mathrm{PGF}_{2 \alpha}$ secretion is desirable for embryo survival because of its known luteolytic properties. Although the transcript levels of AKR1B1 and PTGES were modulated in SC with the addition of ENL, these genes were not affected by ENL in EC. This would suggest that different molecular mechanisms are involved in SC and EC, with respect to the synthesis of $\mathrm{PGE}_{2}$ and $\mathrm{PGF}_{2 \alpha}$. The results presented herein focused on mRNA abundance and PG secretion that were used as a functional endpoint. Since changes in mRNA abundance do not always reflect differences in protein expression, caution needs to be exercised when extrapolating these results to protein expression or activities. Future studies are required to assess whether the effects of the treatments observed on mRNA abundance and PG secretion correlate with protein expression and activities.

\section{Acknowledgements}

The authors thank Danièle Beaudry, Marian Mayhue and Karine L'Ériger for technical assistance, and Steve Methot for his help in the statistical analysis.

The present study was financially supported by grant IPDGR 114 from Agriculture and Agri-Food Canada and through a Natural Sciences and Engineering Research Council of Canada (NSERC) studentship granted to C. Hallé.

The authors' contributions are as follows: C. H. and M. F. P. drafted the manuscript; M. F. P. and H. V. P. conceived and directed the study; C. H. coordinated the study and performed all the experiments; A. K. G. and R. B. provided advice on the experimental design. All authors critically revised the paper and approved the final version of the manuscript.

None of the authors has a personal or professional conflict of interest.

\section{References}

1. Spencer TE, Burghardt RC, Johnson GA, et al. (2004) Conceptus signals for establishment and maintenance of pregnancy. Anim Reprod Sci 82-83, 537-550.

2. Bazer FW, Spencer TE \& Ott TL (1997) Interferon $\tau$ : a novel pregnancy recognition signal. Am J Reprod Immunol 37, $412-420$.

3. Spencer TE, Johnson GA, Bazer FW, et al. (2007) Pregnancy recognition and conceptus implantation in domestic ruminants: roles of progesterone, interferons and endogenous retroviruses. Reprod Fertil Dev 19, 65-78.

4. Xiao CW, Murphy BD, Sirois J, et al. (1999) Down-regulation of oxytocin-induced cyclooxygenase- 2 and prostaglandin $\mathrm{F}$ synthase expression by interferon- $\tau$ in bovine endometrial cells. Biol Reprod 60, 656-663.

5. Arosh JA, Banu SK, Kimmins S, et al. (2004) Effect of interferon- $\tau$ on prostaglandin biosynthesis, transport, and signaling at the time of maternal recognition of pregnancy in cattle: evidence of polycrine actions of prostaglandin $\mathrm{E}_{2}$. Endocrinology 145, 5280-5293.

6. Parent J, Chapdelaine P, Sirois J, et al. (2002) Expression of microsomal prostaglandin $\mathrm{E}$ synthase in bovine endometrium: coexpression with cyclooxygenase type 2 and regulation by interferon- $\tau$. Endocrinology 143, 2936-2943.

7. Pratt BR, Butcher RL \& Inskeep EK (1977) Antiluteolytic effect of the conceptus and of $\mathrm{PGE}_{2}$ in ewes. J Anim Sci 45, 784-791.

8. Lewis CS \& Waterman RN (1985) Metabolism of arachidonic acid in vitro by ovine conceptuses recovered during early pregnancy. Prostaglandins 30, 263-283.

9. Mattos R, Staples CR \& Thatcher WW (2000) Effects of dietary fatty acids on reproduction in ruminants. Rev Reprod $\mathbf{5}$, $38-45$.

10. Schmitz G \& Ecker J (2008) The opposing effects of $n-3$ and n-6 fatty acids. Prog Lipid Res 47, 147-155.

11. Mattos R, Guzeloglu A, Badinga L, et al. (2003) Polyunsaturated fatty acids and bovine interferon- $\tau$ modify phorbol ester-induced secretion of prostaglandin $\mathrm{F}_{2 \alpha}$ and expression of prostaglandin endoperoxide synthase-2 and phospholipase- $\mathrm{A}_{2}$ in bovine endometrial cells. Biol Reprod 69, 780-787.

12. Lessard M, Gagnon N \& Petit HV (2003) Immune response of postpartum dairy cows fed flaxseed. J Dairy Sci 86, $2647-2657$.

13. Robinson RS, Pushpakumara PG, Cheng Z, et al. (2002) Effects of dietary polyunsaturated fatty acids on ovarian and uterine function in lactating dairy cows. Reproduction 124, 119-131.

14. Coyne GS, Kenny DA, Childs S, et al. (2008) Dietary n-3 polyunsaturated fatty acids alter the expression of genes involved in prostaglandin biosynthesis in the bovine uterus. Theriogenology 70, 772-782.

15. Waters SM, Childs S, Sreenan JM, et al. (2007) Effect of dietary polyunsaturated fatty acids on uterine endometrial gene expression of enzymes involved in prostaglandin biosynthesis in cattle. In Proceedings of Irish Agricultural Research Forum, March, Tullamore, Ireland, pp. 27.

16. Bilby TR, Guzeloglu A, MacLaren LA, et al. (2006) Pregnancy, bovine somatotropin, and dietary $n$-3 fatty acids in lactating dairy cows: II. Endometrial gene expression related to maintenance of pregnancy. J Dairy Sci 89, 3375-3385.

17. Ambrose DJ, Kastelic JP, Corbett R, et al. (2006) Lower pregnancy losses in lactating dairy cows fed a diet enriched in $\alpha$-linolenic acid. J Dairy Sci 89, 3066-3074.

18. Petit HV, Germiquet C \& Lebel D (2004) Effect of feeding whole, unprocessed sunflower seeds and flaxseed on milk production, milk composition, and prostaglandin secretion in dairy cows. J Dairy Sci $\mathbf{8 7}, 3889-3898$.

19. Petit HV \& Twagiramungu H (2006) Conception rate and reproductive function of dairy cows fed different fat sources. Theriogenology 66, 1316-1324.

20. Petit HV \& Benchaar C (2007) Milk production, milk composition, blood composition, and conception rate of transition dairy cows fed different profiles of fatty acids. Can J Anim Sci 87, 591-600. 
21. Gagnon N, Cortes C, da Silva D, et al. (2009) Ruminal metabolism of flaxseed (Linum usitatissimum) lignans to the mammalian lignan enterolactone and its concentration in ruminal fluid, plasma, urine and milk of dairy cows. Br J Nutr 102, 1015-1023.

22. Landete JM (2012) Plant and mammalian lignans: a review of source, intake, metabolism, intestinal bacteria and health. Food Res Int 46, 410-424.

23. Bauersachs S, Mitko K, Ulbrich SE, et al. (2008) Transcriptome studies of bovine endometrium reveal molecular profiles characteristic for specific stages of estrous cycle and early pregnancy. Exp Clin Endocrinol Diabetes 116, 371-384.

24. Bauersachs S, Ulbrich SE, Gross K, et al. (2006) Embryoinduced transcriptome changes in bovine endometrium reveal species-specific and common molecular markers of uterine receptivity. Reproduction 132, 319-331.

25. Klein C, Bauersachs S, Ulbrich SE, et al. (2006) Monozygotic twin model reveals novel embryo-induced transcriptome changes of bovine endometrium in the preattachment period. Biol Reprod 74, 253-264.

26. Palin MF, Beaudry D, Vallée M, et al. (2009) Development of a two-species cDNA microarray for transcriptional profiling of sow and dairy cow reproductive traits. J Anim Sci 91, 476-477.

27. Palin MF, Brochu-Gaudreau K \& Small JA, et al. (2006) Use of subtractive hybridization to identify genes affected by omega 3 fatty acids in day 17 embryos and endometrial tissues. In Proceedings of the 8th World Congress on Genetics Applied to Livestock Production, 13-18 August 2006, Belo Horizonte, Minas Gerais, Brazil, pp. 11-12

28. Short EC Jr, Geisert RD, Helmer SD, et al. (1991) Expression of antiviral activity and induction of $2^{\prime}, 5^{\prime}$-oligoadenylate synthetase by conceptus secretory proteins enriched in bovine trophoblast protein-1. Biol Reprod 44, 261-268.

29. Pru JK, Austin KJ, Haas AL, et al. (2001) Pregnancy and interferon- $\tau$ upregulate gene expression of members of the 1-8 family in the bovine uterus. Biol Reprod 65, 1471-1480.

30. Zhang H \& Lai Q (2004) Transcription and translation of dickkopf-1 in endometrium of pregnant mice during the peri-implantation period. J Huazhong Univ Sci Technolog Med Sci 24, 625-627, 638.

31. Stumpo DJ, Byrd NA, Phillips RS, et al. (2004) Chorioallantoic fusion defects and embryonic lethality resulting from disruption of $Z f p 36 L 1$, a gene encoding a $\mathrm{CCCH}$ tandem zinc finger protein of the Tristetraprolin family. Mol cell biol 24, 6445-6455.

32. Fortier MA, Guilbault LA \& Grasso F (1988) Specific properties of epithelial and stromal cells from the endometrium of cows. J Reprod Fertil 83, 239-248.

33. Ireland JJ, Murphee RL \& Coulson PB (1980) Accuracy of predicting stages of bovine estrous cycle by gross appearance of the corpus luteum. J Dairy Sci 63, 155-160.

34. Arosh JA, Parent J, Chapdelaine P, et al. (2002) Expression of cyclooxygenases 1 and 2 and prostaglandin $\mathrm{E}$ synthase in bovine endometrial tissue during the estrous cycle. Biol Reprod 67, 161-169.

35. Xiao CW \& Goff AK (1998) Differential effects of oestradiol and progesterone on proliferation and morphology of cultured bovine uterine epithelial and stromal cells. $J$ Reprod Fertil 112, 315-324.

36. Ramsay TG (2001) Porcine leptin alters insulin inhibition of lipolysis in porcine adipocytes in vitro. J Anim Sci 79, 653-657.
37. Arnold JT, Kaufman DG, Seppälä M, et al. (2001) Endometrial stromal cells regulate epithelial cell growth in vitro: a new co-culture model. Hum Reprod 16, 836-845.

38. Kleinman HK \& Martin GR (2005) Matrigel: basement membrane matrix with biological activity. Semin Cancer Biol 15, 378-386.

39. Mackintosh SB, Schubert HJ, Healy LL, et al. (2013) Polarised bovine endometrial epithelial cells vectorially secrete prostaglandins and chemotactic factors under physiological and pathological conditions. Reproduction 145, 57-72.

40. Caldari-Torres C, Rodriguez-Sallaberry C, Greene ES, et al. (2006) Differential effects of $n-3$ and $n-6$ fatty acids on prostaglandin $\mathrm{F}_{2} \alpha$ production by bovine endometrial cells. J Dairy Sci 89, 971-977.

41. Paupoo AAV, Zhu ZB, Wang M, et al. (2010) A conditionally replicative adenovirus, CRAd-S-pK7, can target endometriosis with a cell-killing effect. Hum Reprod 25, 2068-2083.

42. Parent J, Villeneuve C, Alexenko AP, et al. (2003) Influence of different isoforms of recombinant trophoblastic interferons on prostaglandin production in cultured bovine endometrial cells. Biol Reprod 68, 1035-1043.

43. Weems CW, Lee CN, Weems YS, et al. (1988) Distribution of progesterone to the uterus and associated vasculature of cattle. Endocrinol Jpn 35, 625-630.

44. Guzeloglu A, Michel F \& Thatcher WW (2004) Differential effects of interferon- $\tau$ on the prostaglandin synthetic pathway in bovine endometrial cells treated with phorbol ester. J Dairy Sci 87, 2032-2041.

45. Farmer C, Palin MF, Gilani GS, et al. (2010) Dietary genistein stimulates mammary hyperplasia in gilts. Animal $\mathbf{4}$, 454-465.

46. Applied Biosystems (1997) User Bulletin No. 2: ABI PRISM 7700 Sequence Detection System. Applied Biosystems, Foster City, CA, USA.

47. Vandesompele J, De Preter K, Pattyn F, et al. (2002) Accurate normalization of real-time quantitative RT-PCR data by geometric averaging of multiple internal control genes. Genome Biol 3, RESEARCH0034.

48. Gray CA, Abbey CA, Beremand PD, et al. (2006) Identification of endometrial genes regulated by early pregnancy, progesterone, and interferon $\tau$ in the ovine uterus. Biol Reprod 74, 383-394.

49. Mansouri-Attia N, Aubert J, Reinaud P, et al. (2009) Gene expression profiles of bovine caruncular and intercaruncular endometrium at implantation. Physiol Genomics 39, 14-27.

50. Hansen TR, Austin KJ \& Johnson GA (1997) Transient ubiquitin cross-reactive protein gene expression in the bovine endometrium. Endocrinology 138, 5079-5082.

51. Schmitt RA, Geisert RD, Zavy MT, et al. (1993) Uterine cellular changes in $2^{\prime}, 5^{\prime}$-oligoadenylate synthetase during the bovine estrous cycle and early pregnancy. Biol Reprod 48, 460-466.

52. Fladeby C, Gupta SN, Barois N, et al. (2008) Human PARM-1 is a novel mucin-like, androgen-regulated gene exhibiting proliferative effects in prostate cancer cells. Int $J$ Cancer 122, 1229-1235.

53. Yeon PJ, Jang H, Curry TE, et al. (2013) Prostate androgenregulated mucin-like protein1: a novel regulator of progesterone metabolism. Mol Endocrinol 27, 1871-1886.

54. Xiao CW, Liu JM, Sirois J, et al. (1998) Regulation of cyclooxygenase- 2 and prostaglandin $\mathrm{F}$ synthase gene expression by steroid hormones and interferon- $\tau$ in bovine endometrial cells. Endocrinology 139, 2293-2299.

55. Ulbrich SE, Meyer SU, Zitta K, et al. (2011) Bovine endometrial metallopeptidases MMT14 and MMP2 and the 
metallopeptidase inhibitor TIMP2 participate in maternal preparation of pregnancy. Mol Cell Endocrinol 332, 48-57.

56. Grant-Tschudy KS \& Wira CR (2005) Hepatocyte growth factor regulation of uterine epithelial cell transepithelial resistance and tumor necrosis factor $\alpha$ release in culture. Biol Reprod 72, 814-821.

57. Cheng Z, Robinson RS, Pushpakumara PGA, et al. (2001) Effect of dietary polyunsaturated fatty acids on uterine prostaglandin synthesis in the cow. J Endocrinol 171, 463-473.

58. Cheng Z, Elmes M, Kirkup SE, et al. (2004) Alteration of prostaglandin production and agonist responsiveness by $n-6$ polyunsaturated fatty acids in endometrial cells from late-gestation ewes. J Endocrinol 182, 249-256.

59. Cheng Z, Abayasekara DRE, Ward F, et al. (2013) Altering $n$-3 to $n-6$ polyunsaturated fatty acid ratios affects prostaglandin production by ovine uterine endometrium. Anim Reprod Sci 143, 38-47.

60. Wathes DC, Abayasekara DR \& Aitken RJ (2007) Polyunsaturated fatty acids in male and female reproduction. Biol Reprod 77, 190-201.

61. Imakawa K, Nagaoka K, Nojima H, et al. (2005) Changes in immune cell distribution an IL-10 production are regulated through endometrial IP-10 expression in the goat uterus. Am J Reprod Immunol 53, 54-64.

62. Omoto Y, Lathe R, Warner M, et al. (2005) Early onset of puberty and early ovarian failure in CYP7B1 knockout mice. Proc Natl Acad Sci U S A 102, 2814-2819.

63. Henricks DM, Dickey JF, Hill JR, et al. (1972) Plasma estrogen and progesterone levels after mating, and during late pregnancy and postpartum in cows. Endocrinology 90, 1336-1342.

64. Abayasekara DR \& Wathes DC (1999) Effects of altering dietary fatty acid composition on prostaglandin synthesis and fertility. Prostaglandins Leukot Essent Fatty Acids 61, 275-287.

65. Adlercreutz H \& Mazur W (1997) Phyto-oestrogens and Western diseases. Ann Med 29, 95-120.

66. Lampe JW, Atkinson C \& Hullar MA (2006) Assessing exposure to lignans and their metabolites in humans. J AOAC Int 89, 1174-1181.
67. Zhou W, Wang G, Han Z, et al. (2009) Metabolism of flaxseed lignans in the rumen and its impact on ruminal metabolism and flora. Anim Feed Sci Technol 150, 18-26.

68. Prasad K (2000) Antioxidant activity of secoisolariciresinol diglucoside-derived metabolites, secoisolariciresinol, enterodiol, and enterolactone. Int J Angiol 9, 220-225.

69. Petit HV, Small JA, Palin MF, et al. (2007) Effects of flaxseed supplementation on endometrial expression of ISG17 and intrauterine prostaglandin concentrations in primiparous dairy cows submitted to GnRH-based synchronized ovulation. Can J Anim Sci 87, 343-352.

70. Fleming JGW, Song G, Choi Y, et al. (2009) Interferon regulatory factor 6 (IRF6) is expressed in the ovine uterus and functions as a transcriptional activator. Mol cell Endocrinol 299, 252-260.

71. Bell SE, Sanchez MJ, Spasic-Boskovic O, et al. (2006) The RNA binding protein Zfp3611 is required for normal vascularisation and post-transcriptionally regulates VEGF expression. Dev Dyn 235, 3144-3155.

72. Zakrzewska E, Madore $\mathrm{E} \&$ Chapdelaine $\mathrm{P}$, et al. (2005) Downregulation of AKR1B1 and MPGES1 by RNA silencing reduces prostaglandin production in human endometrial cells. In Annual Meeting, Society for the Study of Reproduction: Biology of Reproduction, Special Issue: M760 (Abstract).

73. Parent J \& Fortier MA (2005) Expression and contribution of three different isoforms of prostaglandin E synthase in the bovine endometrium. Biol Reprod 73, 36-44.

74. Parent J, Villeneuve C \& Fortier MA (2003) Evaluation of the contribution of cyclooxygenase 1 and cyclooxygenase 2 to the production of $\mathrm{PGE}_{2}$ and $\mathrm{PGF}_{2 \alpha}$ in epithelial cells from bovine endometrium. Reproduction 126, 539-547.

75. Thatcher WW, Guzeloglu A, Mattos R, et al. (2001) Uterineconceptus interactions and reproductive failure in cattle. Theriogenology 56, 1435-1450.

76. Ringbom T, Huss U, Stenholm A, et al. (2001) Cox-2 inhibitory effects of naturally occurring and modified fatty acids. J Nat Prod 64, 745-749. 